\title{
Institutional Investor Expectations, Manager Performance, and Fund Flows
}

\author{
Howard Jones and Jose Vicente Martinez*
}

\footnotetext{
* Jones (howard.jones@sbs.ox.ac.uk) is at the Saïd Business School, University of Oxford, Oxford OX1 1HP (tel: (0)1865 288407); Martinez (jose.martinez@business.uconn.edu) is at the University of Connecticut, School of Business. We are grateful to Shantaram Hegde, Tim Jenkinson, Andrew Lo, Rick Di Mascio, Thomas Noe, Tarun Ramadorai, and Peter Tufano for valuable comments, as well as to seminar participants at the Oxford-MAN Institute of Quantitative Finance and at the FCA conference on asset management. We should like to thank Greenwich Associates and eVestment for making available and explaining their databases, for assistance in building the combined dataset, and for valuable insights on the analysis. We also gratefully acknowledge the help of research assistants Edward Coe and Oliver Jones.
} 


\begin{abstract}
Using survey data we analyze institutional investors' expectations about the future performance of fund managers and the impact of those expectations on asset allocation decisions. We find that institutional investors allocate funds mainly on the basis of fund managers' past performance and of investment consultants' recommendations, but not because they extrapolate their expectations from these. This suggests that institutional investors base their investment decisions on the most defensible variables at their disposal, and supports the existence of agency considerations in their decision making.
\end{abstract}

Key words: Institutional asset management, asset flows, fund performance, service quality, investment consultants

JEL classification: G20, G23, G30 


\section{Introduction}

Academic studies of asset management have traditionally found a strong relationship between past performance and investor-directed fund flows (see, e.g., Del Guercio and Tkac (2002), Goyal and Wahal (2008) for institutional investors; or Ippolito (1992), Chevalier and Ellison (1997), Sirri and Tufano (1998), Goriaev, Nijman, and Werker (2008) for individual investors). ${ }^{1}$ Such studies frequently attribute this relationship to investors interpreting past performance as a signal of manager quality or ability (Ippolito (1992)) and either assuming that past performance will persist (Lynch and Musto (2003)), or, as in Berk and Green's (2004) influential model, that outperforming managers will attract assets to the point that decreasing returns to size result in no expected differences in future performance.

An alternative explanation for the importance of past performance is that plan sponsors are conflicted. Lakonishok, Shleifer, and Vishny (1992) see the responsiveness of plan sponsors to past performance as possible evidence of agency problems within the sponsor's organization. Plan sponsor officials, as fiduciaries, have reasons to value manager characteristics that are easily justified to superiors or a trustee committee. One important characteristic is an asset manager's past performance, which is readily observable by the stakeholders of the plan to whom plan sponsor officials are answerable. ${ }^{2}$

\footnotetext{
${ }^{1}$ Institutional investors include retirement plans, foundations, and university and other endowments (see Section II). In this paper we refer to them as 'plan sponsors' to distinguish them clearly from asset managers.

${ }^{2}$ As Lakonishok et al. (1992) explain, 'the treasurer's office may fire a poorly performing manager as part of a scapegoat strategy, or it may hire a stellar past performer in order to avoid being second-guessed ex post.' ((1992), p. $371)$.
} 
In this paper we analyze the interplay between past performance, expectations of future performance, and asset flows to see how the facts stack up against the various explanations advanced for the flow-performance relationship. Using thirteen years of survey data from Greenwich Associates covering plan sponsors with half of the institutional holdings of U.S. equities, we establish a measure of the future performance which plan sponsors expect from their asset managers. We then analyze these expectations as a function of three sets of possible determinants: first, the past performance of the asset managers; second, various non-performance attributes which plan sponsors identify in those asset managers; third, the recommendations of asset managers by investment consultants. Next we set plan sponsors' expectations, and the possible drivers of these expectations, against the actual future performance of the asset managers. Finally, we compare plan sponsors' expectations of asset manager performance, as well as their past performance, consultants' recommendations, and other factors, with the fund flows in and out of asset managers.

This analysis allows us to explore whether the well documented correlation between fund flows and past performance results from investors extrapolating future performance from past performance and acting on their expectations, or from investors chasing past performance in itself. If the correlation between fund flows and past performance results from plan sponsors extrapolating future performance from past performance (as implied by Lynch and Musto (2003) or Ippolito (1992), or as would happen in Berk and Green's framework, if some factor prevented the full equilibrium from playing out - see Berk and Tonks (2007)), then any influence of past performance on flows should be channeled through its effect on the expectation of future performance: to the extent that these measures disagree, only expected future performance should be significant in a multivariate regression. On the other hand, suppose that flows respond 
to past performance for its own sake, as implied by Lakonishok et al. (1992). In this case we should observe flows responding to past performance rather than to expected future performance, and only past performance should be significant in a multivariate analysis.

Our analysis also allows us to extend recent work on investment consultants' recommendations. Jenkinson, Jones, and Martinez (forthcoming) find that consultants' recommendations have a very significant impact on funds flows, but they find no evidence that these recommendations add value to those who follow them. In the present paper we examine the extent to which consultants' recommendations affect the formation of plan sponsors' expectations about the performance of their asset managers, and compare this with the effect of these recommendations on flows. As with past performance, we assess whether the impact of consultants' recommendations on flows is channeled entirely through expectations, or whether these recommendations have an influence on flows which is distinct from their effect on expectations.

Our results are as follows. Plan sponsors' expectations of future performance are driven by past performance (consistent with the prevailing view of the early flow-performance literature), by the soft factors which they identify in their asset managers, and, marginally, by investment consultants' recommendations. However, fund flows are at most only marginally a function of plan sponsors' expectations; rather, they are driven significantly by past performance and by investment consultants' recommendations, far beyond the effect that these have on expectations. Our results point to plan sponsors responding to past performance and consultants' recommendations for their own sake rather than because they extrapolate future performance from these measures. Nonetheless, we find that neither plan sponsors' expectations, nor past 
performance, nor the non-performance factors they evaluate in their asset managers, reliably predict the performance of those asset managers.

These findings are difficult to reconcile with Berk and Greene's (2004) model or with any model of rational non-conflicted investors. However, they do shed light on the relation between past performance, expected performance, and asset flows. The partial dependency of expected performance on past performance and soft factors points to plan sponsors using such variables as signals of future performance even though, as we find, all these variables are uninformative about future performance. The extrapolation of expectations from past performance is consistent with the view, common in this literature, that investors form expectations of future performance by extrapolating past performance. ${ }^{3}$ However, the fact that investors do not act fully on their own expectations, but follow past performance and consultants' recommendations when making investment decisions, is consistent with agency effects. According to this explanation, plan sponsors chase past performance and consultants' recommendations because they feel that, as a rationale for selecting asset managers, these indicators are more defensible to their superiors, stakeholders and, possibly, the courts than their own expectations are. Since past performance and consultants' recommendations are widely followed measures, plan sponsors also know that, if they fail, they will be in good company. To this extent our findings support the suggestions in Lakonishok et al. (1992) that plan sponsors implement herding and scapegoating strategies and their decisions are affected by their interest in deflecting responsibility.

\footnotetext{
${ }^{3}$ This view is also common in other environments (see e.g., De Bondt (1993), or Lakonishok, Shleifer, and Vishny (1994)).
} 
The remainder of the article is organized as follows. Section II summarizes the institutional background and sources of data, Section III outlines our methodology and documents the results of our analysis, and Section IV concludes.

\section{Institutional Background and Data Sources}

\section{A. Institutional Background}

'Plan sponsors' can be broken down into those responsible for retirement plans and those responsible for nonprofit assets. Retirement plans comprise corporate and public pension schemes, some managed for a single employer, others for more than one employer (Taft-Hartley multiemployer plans). Non-profit entities include foundations as well as university and other endowments. Based on Greenwich Associates data, U.S. plan sponsors' assets, at the end of 2011, amounted to some $\$ 7.6$ trillion, broken down as follows: corporate pension funds $38 \%$, public pension funds $47 \%$, foundations and endowments $11 \%$, and unions $4 \%$.

Once plan sponsors have determined the apportionment of assets between asset classes, they tend to delegate the management of the funds within each class to outside asset managers. Asset managers may be hired and fired for a number of reasons, and not only for performance

reasons. Thus, plan sponsors may make a strategic switch between asset classes (e.g., from equities to fixed income), or between styles (e.g., from value to growth), which could lead to the termination of a manager regardless of performance. On the other hand, plan sponsors may increase or decrease the funds delegated to asset managers without hiring or firing them: 
imbalances between (employer/employee) contributions and payments (to beneficiaries) may cause plan sponsors to vary the volume of funds delegated to existing managers.

In selecting asset managers, many plan sponsors take the advice of investment consultants. Plan sponsors use consultants' recommendations both when they first hire managers in an asset class, and when they replace managers within an asset class. As part of the hiring procedure, the consultant typically recommends a short list of fund managers, and the sponsor, advised by the consultant, chooses from among them. Estimates of the usage of investment consultants by plan sponsors vary, but suggest that it is widespread. According to the Pensions and Investments survey of plan sponsors (2011), 94\% of plan sponsors employ an investment consultant. Goyal and Wahal (2008) find that consultant usage varies by type of sponsor: thus half of corporate pension plans in their sample use a consultant, while $82 \%$ of local public plans do so. However, although plan sponsors may take advice from investment consultants, the fiduciary responsibility to select fund managers lies with the plan sponsors themselves.

\section{B. Data Sources}

In compiling our dataset we draw on two sources. The first comprises two series of surveys conducted by Greenwich Associates between 1999 and 2011. In one of these series, plan sponsors rate the asset managers they have appointed on various measures of performance and service. In the second series of surveys, investment consultants rate asset managers on the same 
set of measures, and also name the asset managers they recommend for each of a number of investment size-styles categories. ${ }^{4}$

The second source we use is a set of data provided by eVestment on the returns of institutional U.S. equity asset managers and their assets under management (AUM) for the same period. We limit our analysis to U.S. long-only active equity asset managers. We provide further details below of each database, and of the way in which they are combined in our dataset.

The Greenwich surveys. Since 1972 Greenwich Associates (GA) have conducted an annual survey of the judgements of plan sponsors on their asset managers. We draw on the surveys between 1999 and 2011. Before 1999 the GA survey is less complete, and it does not include questions on respondents' perception of the performance of asset managers, which is central to our analysis. For each year in this period the survey was carried out over a two- to three-month period starting between late June and early September of the same year. To our knowledge this is the longest-standing, most complete survey of plan sponsors available. According to GA, the fraction of the total universe of U.S. plan sponsors responding to the survey averaged $54 \%$ for the period; coverage has fluctuated during that period, and stood at 62\% (1484 respondents) in 1999 against $43.5 \%$ (987 respondents) in 2011. The total AUM invested by the respondent plan sponsors for 2011, the end of the period, stood at $\$ 3.95$ trillion, or $52 \%$ of the AUM of the total

\footnotetext{
${ }^{4}$ Survey data play an important part in economics research, e.g. in the inflation expectations literature, where they are used as a means to access expectations directly rather than inferring them from other data (see e.g., Carroll (2003), Leduc, Sill, and Stark (2007), Armantier, Bruine de Bruin, Topa, van der Klaauw, Zafar (2011), Chernov and Mueller (2012)). We attempt something similar: to analyze expectations without merely inferring them from actions (in this case asset flows) precisely in order to identify any mismatch between expectations and actions. For an example of the use of survey data to examine agency problems in corporate pension plans, see Rauh (2009).
} 
universe of U.S. plan sponsors identified by GA. The breakdown of AUM by type of respondent for 2011 is as follows: corporate pension funds (43\%), public-sector pension funds $(45 \%),{ }^{5}$ endowments and foundations (9\%), and unions (3\%).

Respondents to the survey tend to express opinions on the entire asset class of the asset management group within which their funds are managed, (e.g., U.S. Domestic Equity managed by Firm ABC, International Fixed Income managed by Firm XYZ) rather than on products (i.e., groups of funds with essentially the same mandate), or on the individual funds within that class. Within each plan sponsor the GA questionnaire is answered by executives with a range of titles from Chairman of the Board to Assistant Treasurer. The most common title of the respondents is Chief Investment Officer. The incentive to answer the questionnaire is that the respondent's firm has access for the following twelve months to the aggregate results both of that survey and of other GA surveys. Responses to the questionnaire are private. However, respondents may allow their judgements on individual asset management firms to be made available to those firms; during the sample period around 50-60\% of respondents chose to do so.

The headings under which respondents are asked to rate asset managers are divided by GA into two sets: investment factors and service factors. For each factor the respondent is invited to rate an asset manager's performance in each asset class on a five-point scale. Two of the investment factors are 'performance factors' and reflect the respondents' appraisal of asset managers' performance: one is the respondent's assessment of the performance of the asset manager over the previous 2-3 years (past performance), and the other is the performance the

\footnotetext{
${ }^{5}$ The pension funds captured in the survey include both defined-benefit (DB) and defined-contribution (DC) schemes. However, only pension-fund-directed DC schemes are included, and not participant-directed schemes, since in these the investment decisions are taken by the beneficiaries, not by the pension fund.
} 
respondent expects from the asset manager (expected future performance). The other three investment factors, which we call 'soft investment factors', are clear decision making, capability of portfolio manager, and consistent investment philosophy. The second set of categories in which asset managers are rated, the service factors, are as follows: useful informal meetings, capable relationship manager, useful formal meetings, credibility with investment committee, understanding objectives, and useful written reports. Under each factor GA then aggregates the responses into a single score for each asset manager in each asset class surveyed using the Rasch model (see Andrich (1978)). We work with a modified version of these scores, the fractional rank, obtained by ranking the asset manager's scores for each variable into percentiles and dividing them by 100 to arrive at a factor for each manager between 0 and 1.

Table 1 provides summary statistics for the 2011 plan sponsors survey, the most recent survey used in our study, and one of two for which we have disaggregated data. On average, each question is evaluated by 781 respondents (plan sponsors), and each expresses opinions on multiple asset managers, giving an average of 3,194 evaluations for each question in the survey.

[Place Table 1 around here]

Plan sponsors respond to survey questions only about asset managers that they have appointed. This ensures that their responses on different managers are similarly well informed. As Table 1 shows, mean response scores in all categories lie towards the top of the 1-5 range, which is not surprising given that plan sponsors are evaluating managers which they presumably rated highly in the recent past. Negative views are less likely to appear in the survey than if plan sponsors were rating managers they had not appointed. However, as we use relative rankings, 
this should not be a problem. What is important is that respondents discriminate between asset managers effectively on the various survey measures. As Table 1 shows, this is the case. The $F$ test of identical means and the Kruskal-Wallis test (a non-parametric alternative to the $F$-test more appropriate for ordinal data) show that the separation is effective across the question set; in particular, the responses are just as discriminating (and no more noisy) to questions on expected future performance as they are to those on past performance. These tests suggest that survey responses are informative about the variables of interest.

GA also conduct an annual survey of investment consultants, in which they ask consultants to recommend between four and six asset managers for each of a number of sizestyle categories (e.g., Large Cap Growth, Small Cap Value). With these responses we create a single measure to reflect investment consultants' recommendations of each asset management firm for which we also have plan sponsor survey data. We combine consultants' recommendations for the same asset manager's different investment size-style categories to match them with plan sponsors' responses, which are given at the level of the asset class and not broken down by size-style category (see Internet Appendix for details). The consultants' recommendation measure for each asset manager is expressed as a percentage of the most recommendations which that asset manager could possibly have received across all size-style categories from all consultants combined. In our sample period the survey of investment consultants occurred between November and March. The consultants' recommendation measure for each asset manager is based on the survey of consultants conducted immediately before the plan sponsor survey. The GA survey covers consultants with a share of over $90 \%$ of the U.S. consulting market; for further details, see Internet Appendix and Jenkinson et al. (forthcoming). 
The eVestment database. eVestment is a third-party provider of analytic services for the institutional fund management industry. We use two parts of their database: one which tracks the monthly and quarterly returns of institutional asset managers, and one which tracks those funds' AUM (at an annual, and sometimes quarterly, frequency). The returns we obtain are 'composite' returns: the individual returns earned by each client may deviate from these composite returns, but deviations are typically small. ${ }^{6}$ Composite returns are net of trading costs, but gross of investment management fees. The data are self-reported by the asset managers, but constant scrutiny from clients using this data guarantees a high degree of accuracy. The return data are free from survivorship bias. For each product, the databases also provide cross-sectional information on investment style and capitalization bracket, manager-designated benchmark, and the latest fees. The data on AUM relate only to plan sponsors' assets. The eVestment database were first compiled in 2000, but include data from before that date. As at the end of 2012, the eVestment database had data on 4,274 U.S. equity funds which were active, and around 2,500 which were inactive (i.e., no longer reporting). One limitation of the database (commented on below) is that, once an asset manager is acquired and absorbed by the acquirer (rather than retaining its distinct identity), eVestment may not report data separately for the acquired firm for the period before the acquisition. This may introduce some noise, or even some form of survivorship bias, in the results.

Combining the databases. To match the eVestment data to the GA asset class of Domestic U.S. Equity, we first eliminate index funds, hedge funds, real estate investment trusts (REITs), and retail funds from the eVestment database. We keep a small number of 'enhanced index funds',

\footnotetext{
${ }^{6}$ For example, some investors may require that their part of the overall portfolio includes no tobacco companies.
} 
i.e. active funds aiming at a small outperformance of a given index, as these are active funds whose risk adjusted performance we can evaluate like that of any other. There are 347 unique asset manager names in the GA database (with 2,485 lines of data for the whole period). We match these unique GA asset manager names to the eVestment database, eliminating 115 in the process. The names eliminated fall into three categories: (i) fourteen names for which GA has only one year's data, which rules out any time series analysis; (ii) twelve names for which there is more than one possible match in the eVestment database; (iii) 89 GA names which do not appear in the eVestment database. We identify 20 of these as firms that were acquired and absorbed by the acquirer but, since their performance and flow data are consolidated with those of the acquirer in the eVestment database even for the period before the acquisition, we eliminate them from the dataset. These eliminations leave us with 232 asset manager unique names (and 1,630 lines of data for the sample period).

The GA responses from each asset management group are for a size-style category, e.g. Large Cap Growth, whereas the performance and flow data from eVestment is by individual fund. We therefore group together in the eVestment database funds managed by a single asset management group which correspond to a given asset manager/asset class category in the GA survey. Thus, if there are four individual funds in the eVestment database in the category Large Cap Growth for Firm XYZ, we combine their performance and flow information data in eVestment, allowing like-for-like comparison with the GA survey responses. In grouping fundlevel data from eVestment in this way, we use a weighted average of the individual funds to measure performance, and we aggregate flow information. For further details on combining the GA and eVestment database, see Internet Appendix. 
Table 2 provides descriptive statistics for the final sample. The availability of AUM data is high for the period with the exception of the first years (end of year asset data are available for approximately $90 \%$ of the asset managers). Average assets in the U.S. domestic active equity asset class per asset manager in the sample period are $\$ 18.9$ billion.

[Place Table 2 around here]

\section{Methodology and Results}

\section{A. How are Expectations of Future Performance Formed?}

There is little evidence in the literature about how plan sponsors form their expectations of asset manager performance. One possible parallel is the extensive research on financial analysts' earnings forecasts and expectations (see Ramnath, Rock, and Shane (2008) for a survey). However, there are important differences between the incentives under which analysts produce their earnings forecasts and those which apply to the respondents in the GA survey. Analysts' forecasts are affected by an incentive structure liable to be inconsistent with conditionally unbiased forecasting, and many people argue that they cannot therefore be used as valid proxies for true expectations. ${ }^{7}$ By contrast, we work with plan sponsors' anonymous

\footnotetext{
${ }^{7}$ The non-anonymous nature of earnings forecasts is thought to expose financial analysts to conflicting incentives. Examples of the incentives faced by financial analysts are a desire: to win investment banking business (Lin, and McNichols (1998), Dugar and Nathan (1995)); to generate trading commissions (Dorfman (1991)); to please corporate managers (Francis and Philbrick (1993)); or to follow career concerns (Hong, Kubik, and Solomon (2000)).
} 
forecasts of asset manager performance, which are more likely to be faithful revelations of true expectations.

Our emphasis is not on fully-fledged tests of rationality in (individual) expectations, but on an exploratory analysis of aggregate expectations: what they depend on, and whether these variables have any predictive power over actual future performance ranks. ${ }^{8}$

We explore what drives aggregate expectations of future performance by estimating the following model on yearly data:

$$
\begin{aligned}
\text { EXPECTED_PERF }_{i, t}= & \alpha+\beta_{1} \text { PAST_PERF }_{i, t}+\beta_{2} \text { SOFT_INV_FACTORS }_{i, t}+ \\
& \beta_{3} \text { SERVICE_FACTORS }_{i, t}+\beta_{4} \text { CONSULTANTS_RECS }_{i, t}+ \\
& \delta^{\prime} \text { CONTROLS }_{i, t-1}+\epsilon_{i, t},
\end{aligned}
$$

where EXPECTED_PERF $i, t$ is the fractional rank at time $t$ of the aggregate expected future performance of asset manager $i$ 's U.S. equity products in coming years; PAST_PERF $F_{i, t}$ is the fractional rank at time $t$ of the aggregate performance of asset manager $i$ 's U.S. equity products in the recent past (two to three years); SOFT_INV_FACTORS ${ }_{i, t}$ is the fractional rank at time $t$ of a set of soft investment factors of asset manager i's U.S. equity team (see Section II for a list of these factors); SERVICE_FACTORS ${ }_{i, t}$ is the fractional rank at time $t$ of a set of service factors of asset manager $i$ 's U.S. equity team (see Section II for a list of these factors); and

\footnotetext{
${ }^{8}$ Like many other studies, we analyse mean survey responses, the data available to us. As noted by Figlewski and Wachtel (1983) and Keane and Runkle (1990), using average survey response data rather than individual data can be problematic if the objective is to assess the rationality of the underlying individual expectations. Basu and Markov (2004) argue, however, that, to the extent that individual investors' errors in processing information average out, the average responses are likely to be more accurate and closer to optimality than the individual survey responses.
} 
CONSULTANTS_RECS ${ }_{i, t}$ is the number of recommendations asset manager $i$ received at time $t$, as a fraction of the most recommendations that asset manager could have possibly received across all the size-style categories from all consultants in our sample. Fractional ranks, giving the asset manager's percentile rank relative to other asset managers in the same size-style category and period, range from 0 to 1 (see Sirri and Tufano (1998) for further details). ${ }^{9}$

Table 3 reports the results of running this regression using pooled time-series crosssectional data. Each column represents a separate regression corresponding to three alternative specifications of equation (1). In these specifications past performance is proxied using reported past performance (in the survey) or past excess return over benchmarks (selected by eVestment) computed over the two-year period to the end of the month preceding the survey. ${ }^{10}$ All these specifications include a lagged measure of log assets under management, return volatility, and a full set of time dummies as controls. All survey variables in the regressions refer to the asset class of U.S. active equities only. Since survey respondents are asked to evaluate past and future performance over multiple overlapping periods, $t$-statistics reported in the table are based on standard errors clustered at the asset manager level (White (1980), Rogers (1993)).

\section{[Place Table 3 around here]}

\footnotetext{
${ }^{9}$ Using the fractional ranks transformation for both GA scores and various past and future performance measures allows for direct comparison between the two.

${ }^{10}$ To generate aggregate past excess returns over benchmarks we create equal-weighted portfolios of all U.S. active equity products available from each asset manager in each month. We then compute the average return of the portfolio of products in excess of a similarly defined portfolio of benchmarks (selected by eVestment).
} 
Results indicate that past performance is the key driver of plan sponsors' expectations of asset managers' future performance. Estimates in Table 3 indicate that moving from the 25th percentile of reported past performance to the 75th percentile results in an increase of 24 percentiles in expected future performance. Using past excess returns over benchmarks to proxy for past performance, gives somewhat lower, but likewise significant, estimates for the effect of changes in past performance on expectations of future performance. ${ }^{11}$ In the Internet Appendix we show that the same happens if we use past Fama-French (1993) three factors alphas to proxy for past performance. This result is consistent with the view, common in the flow performance literature, that investors form expectations of future performance by extrapolating past performance. It also indicates that, in forming expectations, plan sponsors ignore the evidence that suggests that asset managers' past investment performance is of little help in predicting future performance over horizons long enough for plan sponsors to exploit (see, e.g., Carhart (1997), Busse et al. (2010)).

Results in Table 3 also indicate that expectations of future performance are driven by soft investment factors, e.g. being perceived as having capable investment professionals or a clear decision-making process, and, to a lesser but still significant extent, service factors - as well as by past performance. The strong link between soft investment factors and investors' expectations of future performance is unsurprising, since these factors reflect the quality of decision makers or

\footnotetext{
${ }^{11}$ The difference in results depending on whether we use reported past performance or past excess returns over benchmarks could reflect two phenomena. First, past excess returns over benchmarks (or three factor alphas) may not coincide with what plan sponsors consider when they report past performance: the period they have in mind, and the basis of performance measurement, may be different. Second, the higher coefficient on reported past performance than on actual past performance may be due to plan sponsors projecting expectations of future performance onto past performance. We discuss these two possibilities at greater length in section B.
} 
decision making processes, which are typically thought to lead to investment success. However, service factors (such as meeting preparation/follow-up, useful informal meetings, and a capable relationship manager), which appear unrelated to investment results, also seem to have a significant impact on expectations. This is perhaps because plan sponsors read service factors as informative about the general business practices of the asset manager, which might also be reflected in expected future performance. Investment consultants' recommendations also seem to affect expectations of future performance: asset managers experiencing an increase in the number of consultants who short-list them are perceived as more likely to outperform other asset managers, but this effect is rather mild.

While past performance, soft investment factors and service factors, and consultants' recommendations all seem to drive expectations of future performance, it is unclear whether these factors have any predictive power over actual future performance. We explore whether that is the case by replacing expected future performance in equation (1) with a measure of actual future performance, to estimate the following model:

$$
\begin{aligned}
\text { PERF }_{i, t+1}= & \alpha+\beta_{1} \text { PAST_PERF }_{i, t}+\beta_{2} \text { SOFT_INV_FACTORS }_{i, t}+\beta_{3} \text { SERVICE_FACTORS }_{i, t}+ \\
& \beta_{4} \text { CONSULTANTS_RECS }_{i, t}+\delta^{\prime} \text { CONTROLS }_{i, t-1}+\epsilon_{i, t},
\end{aligned}
$$

where $\mathrm{PERF}_{i, t+1}$ is the actual excess return fractional rank of manager $i$ 's U.S. active equity products over the next one or two years; and other variables are defined as before.

Excess returns are computed starting from the month after the close of the survey and ending a full year later. Again, to generate this aggregate measure of performance, we create equal-weighted portfolio returns of all U.S. active equity products of each asset manager in each 
month. With these returns we compute the average return of the portfolio of products against a similarly defined portfolio of benchmarks.

The results, presented in Panel A of Table 4, show that future performance is largely unpredictable from past performance, and also from plan sponsors' evaluation of managers' nonperformance qualities. Consultants' recommendations, aggregated at the manager level, also seem largely unrelated to performance. Similar results obtain whether we use one- or two-year excess returns or three-factor alphas (see Internet Appendix), or one- or four-factor alphas (corresponding to the Capital Asset Pricing Model, see Sharpe (1964); and Fama-French-Carhart four-factor model, Carhart (1997)).

[Place Table 4 around here]

Taken together, the results in Tables 3 and 4 suggest that plan sponsors' expectations of future performance are systematically biased in the direction of past performance, and also in the direction of managers who are perceived as having good soft investment and service qualities. While plan sponsors may expect that managers whom they perceive to have done well in the past, to have clear decision making processes and capable and credible investment professionals, will display superior future performance, this is usually not the case.

Even though institutional investors' forecasts of future performance rely partly on variables with no predictive power over future performance, and are therefore biased in that direction, they could still be informative about actual future performance. To explore this possibility we expand the regression in equation (2) to include expected future performance rankings as one of the regressors. Results, displayed in Panel B of Table 4, indicate that expected 
future performance is a poor predictor of actual future excess returns, suggesting that it does not contain any information about future performance (similar results obtain whether we use one- or two-year excess returns or three-factor alphas).

Overall, the findings in this section are in line with the traditional view in the flowperformance literature (see Lynch and Musto (2002)) to the extent that plan sponsors extrapolate from past performance when forming their expectations. Our findings are also consistent with Berk and Green (2004) in the sense that plan sponsors read past performance as a quality signal, but not with the full equilibrium in their model, in which rational investors expect the future performance of all asset managers to be the same, on the grounds that asset managers who did well in the past will attract more assets, making outperformance impossible.

\section{B. Do Asset Flows Respond to Expected Future, or Past, Performance and Non- Performance Indicators?}

Arguably, the sole concern of plan sponsors should be the future performance of their investments. If so, and to the extent that their views on the future performance of different asset managers differ, we should expect asset flows to respond to changes in expected future performance. This is in fact the traditional view in the flow-performance literature, in which investors not only extrapolate expectations from past performance (as we find above), but also act on these expectations. If this view is correct, past performance (as well as other variables) should affect expectations of future performance, but once we control for expected future performance in a multivariate regression framework, past performance should not have a separate impact on flows. 
Agency problems, however, may lead plan sponsor decision-makers to base their decisions on past performance, even if they think that they know better. In this vein Lakonishok et al. (1992) argue that pension sponsor officials, as fiduciaries, have agency reasons to value manager characteristics that are easily justified to superiors or a trustee committee. One of the most obvious of these characteristics is the past performance of asset managers. To the extent that this is the case, flows would respond to past performance for its own sake, and past performance would be significant in a multivariate analysis.

Agency problems within the sponsor's organization may also reveal themselves in other ways. Plan sponsors, to shield themselves from criticism associated with poor performance by asset managers, may follow investment consultants' recommendations, even if they are unconvinced by their advice (see Lakonishok et al. (1992), Goyal and Wahal (2008)). Similarly if, as Lakonishok et al. (1992) claim, asset managers provide a hand-holding service to pension officers, institutional asset flows may also respond to perceived changes in the level of service received from asset managers.

We explore these issues by measuring how flows respond to lagged past, and expected future, investment performance, to changes in investment consultants' recommendations, and to variables measuring soft service quality attributes. We estimate the response of flows to these variables using the following regression on yearly data:

$$
\begin{aligned}
\text { FLOW }_{i, t}= & \alpha_{t}+\beta_{1} \text { EXPECTED_PERF }_{i, t-1}+\beta_{2} \text { PAST_PERF }_{i, t-1}+ \\
& \beta_{3} \text { SOFT_INV_FACTORS }_{i, t-1}+\beta_{4} \text { SERVICE_FACTORS }_{i, t-1}+ \\
& \beta_{5} \Delta \text { CONSULTNATS_RECS }_{i, t-1}+\delta^{\prime} \text { CONTROLS }_{i, t-1}+\epsilon_{i, t},
\end{aligned}
$$

where $\mathrm{FLOW}_{i, t}=\mathrm{TNA}_{i, t}-\mathrm{TNA}_{i, t-1} \times\left(1+r_{i, t}\right) / \mathrm{TNA}_{i, t-1}, \mathrm{TNA}_{i, t}$ is the total net assets for 
asset manager $i$ at year $t$ in the U.S. active equity asset class, $r_{i, t}$ is the asset weighted average return on asset manager $i$ 's U.S. active equity products between years $t-1$ and $t .{ }^{12}$ This flow measure reflects the growth of a fund above the growth that would have occurred if no new money had flowed in but dividends had been reinvested, and is expressed in percentage terms relative to total assets at the beginning of the period. $\triangle$ CONSULTANTS_RECS $i, t-1$ is the change in the number of recommendations asset manager $i$ received, as a fraction of the most recommendations which that asset manager could have possibly received across all size-style categories from all consultants in our sample, between time $t-2$ and $t-1$. All other variables are defined as before.

Table 5 reports the results of estimating this regression using pooled time-series crosssectional data and including a lagged measure of log assets under management, return volatility, and a full set of time dummies as controls. In Table 5 each column represents a separate regression. For each of the explanatory variables (expected future performance, reported past performance or past excess returns, soft investment factors, and service factors) the coefficient indicates the percentage change in assets in the current year which occurs if one moves from the bottom percentile to the top percentile of that variable. GA plan sponsors' surveys are usually conducted during the second part of the year (the last fielding date is between September and November depending on the year). Given that plan sponsors typically take time to implement investment decisions, it seems natural to use time $t$ - 1 and $t$ - 2 explanatory variables in the analysis.

\footnotetext{
${ }^{12}$ A limitation of annual data is that it may not capture the sensitivity of flows to past performance, and other variables, over periods under one year. However, plan sponsors tend to be slow to react to past performance: we understand from industry sources that plan sponsors often place managers who have performed poorly on a 'watch list' for several months before deciding to replace them. This may reflect the high costs of transition, which can vary between $1 \%$ and $2 \%$ of AUM (see Goyal and Wahal (2008)).
} 
GA investment consultants' surveys, on the other hand, are usually conducted early in the year (the last fielding date is never later than May), so we only lag the recommendations variable one period $(t-1)$ in our analysis. $t$-statistics are based on clustered standard errors, which are White heteroskedastic-consistent standard errors corrected for possible correlation across observations of a given asset manager in all of the regressions (White (1980), Rogers (1993)). ${ }^{13}$

[Place Table 5 around here]

In all four specifications the coefficients on lagged reported past performance or past excess returns over benchmarks (our measures of past performance) are positive and statistically significant. At the same time, the coefficient on lagged expected future performance is either not statistically different from 0 or only mildly significant. The estimates in models 1 to 4 indicate that, on average, moving from the bottom percentile of past performance to the top percentile is rewarded with a $30 \%$ increase in assets for the asset manager; but a similar change in expected future performance has at most a minor impact on asset flows. In models 1 and 2, where we proxy past performance using the reported measure of past performance in the GA survey, the effect of expected future performance on flows is never significant. In models 3 and 4, where we replace reported past performance with asset managers' actual past excess returns over benchmarks, lagged expected future performance becomes a significant predictor of future flows, but its importance is still much smaller than that of lagged excess returns, and it becomes almost

\footnotetext{
${ }^{13}$ This method seems to be the most sensible given the size of our panel (see Petersen (2009)). Similar results obtain if asset manager and time fixed effects are used or if data is clustered in two dimensions, time and manager, as in Cameron, Gelbach, and Miller (2011).
} 
negligible when we control for a more complete set of actual past performance measures (past one or two-year 3-factor alphas or past one-year excess returns over benchmarks - see Internet Appendix). ${ }^{14}$ The estimates in model 2 and 4 also show that the main response of flows to past performance occurs within a little over a year, with no visible effects beyond that.

The reason why the influence of expected future performance on future flows is marginal is not that our expected future performance variable is noisy - a common source of concern with survey data on expected returns (see Lamont (2003), Greenwood and Shleifer (2013)). Although there is likely some noise in individual responses about future expected performance, the results of the two tests of no differences in scores among asset managers reported in Table 1 , the $F$-test of identical means and the Kruskal-Wallis test, indicate that plan sponsors are as effective in separating asset managers by expected future performance as they are by past performance. That is, while there is some disparity in opinions, plan sponsors tend to agree about which asset managers will do well (or not) in an asset class, and they do so to a similar extent as they agree about asset managers' past performance. This suggests that there is no significant difference in quality between the expected future performance variable and reported past performance, also a survey variable; yet when both are included in a multivariate regression framework it is mostly, or even only, past performance that matters for flows. It is also difficult to think that institutional frictions are behind the unresponsiveness of flows to expected future performance. Such frictions could constrain asset movements in the short term but are less likely to affect them in the long

\footnotetext{
${ }^{14}$ Our past excess return and alpha measures are calculated gross of fees. The evidence is that in institutional funds fees are largely homogeneous within size-style categories, so that it does not make a difference if we use returns gross of fees. We have fee records from eVestment for 2012 which show that there is little cross-section variation in fees. This is consistent with Busse, Goyal, and Wahal (2010): '[I]ntrastyle variation in fees is extremely small; almost all of the cross-sectional variation in fees is generated by investment styles' ((2010), p. 772).
} 
run. The fact that neither one- nor two-year lagged expected performance measures have a major impact on flows makes us believe that these frictions are not behind our results.

At the same time, the strong significance of past performance in these regressions does not seem to be the result of plan sponsors projecting their expectations of future performance onto the reported past performance measure either (even when psychological factors are known to affect an individual's perceptions or recollections of past events, see e.g., Goetzmann and Peles (1997)). When we replace reported past performance with non-survey measures of past performance (past excess returns and alphas) these past performance measures remain as significant as before.

The fact that past performance is a much more important driver of flows than expected future performance indicates that institutional investors do not so much allocate funds to those asset managers they think will do well in the future as to those that they think did well in the recent past. This is at variance with the most frequent interpretation of the flow-performance relation that attributes the sensitivity of institutional fund flows to past performance to a belief by investors that past performance will persist into the future. If extrapolative expectations were the main reason why plan sponsors chased past performance, the coefficient on expected future performance, but not that on past performance, would be highly significant when both are part of the regression estimation. That is not the case, however.

One possible explanation for this result, consistent with Lakonishok et al.'s (1992) arguments, is that, for agency reasons, trustees choose to base their decisions on the most observable and verifiable variable at their disposal, past performance, even if they think they know better. Trustees may attach undue weight to this tangible piece of information simply because it is observable by the people they are answerable to. Such behavior is particularly to be 
expected of sponsors who are most sensitive to 'headline risk' (i.e., negative publicity) - the same investors who, according to Goyal and Wahal (2008), are likely to chase investment styles with high recent returns and to terminate managers for poor performance. This behavior is akin to that of money managers said to window-dress their portfolios at year-end by selling poorly performing stocks that the sponsors might take as evidence of low ability (Lakonishok et al. (1991)); or to that of institutional investors who prefer glamour stocks because they appear to be 'prudent' investments, and hence easy to justify to sponsors (Lakonishok et al. (1994)). ${ }^{15}$ It is also consistent with the well-known adage that 'no one got fired for buying IBM'.

A similar agency rationale may explain plan sponsors' reliance on consultants' recommendations. The estimates in models 1 to 4 indicate that asset managers that go from not being short-listed at all by investment consultants to being short-listed by all consultants in the survey for all their products enjoy a 57\% increase in assets (average across models), even after controlling for the effect these recommendations have on plan sponsors' expectations of future performance. This suggests that institutional investors not only follow consultants' recommendations, as we would expect, but that they follow them regardless of their belief in their value. ${ }^{16}$

Regarding service quality, results in Table 5 suggest that fund flows do not respond to measures of service quality, once we control for perceived past and expected future performance. Plan sponsors might use service factors, together with other variables, to infer future

\footnotetext{
${ }^{15}$ For evidence of how the prudent man rule affects fiduciaries' portfolio decisions see also Badrinath, Gay, and Kale (1989) and Del Guercio (1996).

${ }^{16}$ Since the GA investment consultants' surveys occur several months before the plan sponsors' surveys, it seems natural to believe that plan sponsors are aware of consultants' recommendations at the time of answering about their expectations of future performance.
} 
performance, but service quality does not seem to be valuable in itself. This is true when looking at service quality factors together or individually (see Internet Appendix); or even if we consider changes in service quality as the dependent variable instead of levels (not reported).

It could be, however, that service factors are important only if the investment performance of the asset manager is not good or if the quality of these service factors is very poor. To explore these possibilities we estimate the following model:

$$
\begin{aligned}
\text { FLOW }_{i, t}= & \alpha_{t}+\beta_{1} \text { EXPECTED_PERF }_{i, t-1}+\beta_{2}\left[\text { PAST_PERF }_{i, t-1} \times I_{i, t-1}^{\mathrm{PP}}\right]+ \\
& \beta_{3}\left[\text { PAST_PERF }_{i, t-1} \times\left(1-I_{i, t-1}^{\mathrm{PP}}\right)\right]+\beta_{4} \text { SOFT_INV_FACTORS }_{i, t-1}+ \\
& \beta_{5}\left[\text { SERVICE_FACTORS }_{i, t-1} \times I_{i, t-1}^{M}\right]+\beta_{6}\left[\text { SERVICE FACTORS }_{i, t-1} \times\right. \\
& \left.\left(1-I_{i, t-1}^{M}\right)\right]+\beta_{7} \Delta \text { CONSULTANTS_RECS }_{i, t-1}+\delta^{\prime} \text { CONTROLS }_{i, t-1}+\epsilon_{i, t},
\end{aligned}
$$

where $M=\mathrm{PP}$ (Past Performance) or SF (Service Factors), depending on the specification; $I_{i, t-1}^{\mathrm{PP}}$ is an indicator variable equaling 1 if unscaled PAST_PERF $F_{i, t-1}$ is lower than a given threshold and 0 otherwise; and $I_{i, t-1}^{\mathrm{SF}}$ is another indicator variable equaling 1 if unscaled SERVICE_FACTORS $S_{i, t-1}$ is lower than a given threshold and 0 otherwise. PAST_PERF $F_{i, t-1}$ and SERVICE_FACTORS $\mathrm{S}_{\mathrm{i}, t-1}$ are re-scaled by subtracting the threshold value to make this a continuous piecewise linear model. All other variables are defined as before.

The results of estimating this model are presented in Table 6. In addition to the usual statistics Table 6 also reports the $p$-values of an $F$-test of equality of coefficients between the slopes of past performance and service quality above (+) and below (-) a given threshold, defined here as the $33^{\text {rd }}$ percentile of past performance or service quality. Together with the results of Table 5, these results indicate that, while asset flows are in general not very sensitive to past 
service quality, they become more sensitive when service quality is poor (model 2). This is consistent with the view that when service quality is poor investors are more likely to abandon an asset manager but that having good service quality is unlikely to attract funds by itself. It is also consistent with the hypothesis that pension officers value hand-holding, in line with Lakonishok et al. (1992); and indeed, with any interpretation according to which plan sponsors are expected to value a minimum level of service quality from their asset managers. Estimates in model 3, seem, however, to show that service quality is not necessarily more important when performance is bad; this suggests that service quality is valued in general, and not merely to help pension officers explain poor performance.

[Place Table 6 around here]

Estimates in model 1 in Table 6 also suggest that the relation between flows and past performance is nearly linear. This is consistent with the findings of Del Guercio and Tkac (2002) who document a nearly linear relation for pension funds, in contrast to studies of the retail mutual fund industry which typically find a convex relation between flows and performance (e.g. Sirri and Tufano (1998)). ${ }^{17}$

Overall, our findings suggest that plan sponsors allocate funds, not so much to asset managers they think will do well in the future, but to those they think did well in the recent past and to those recommended by investment consultants. This finding is at odds with theories that interpret past performance merely as a signal of manager quality or ability, and instead points to agency problems. It is consistent with trustees basing their decisions on the most defensible

\footnotetext{
${ }^{17}$ Some $90 \%$ of the plan sponsors in our sample (by AUM) are pension funds.
} 
variables at their disposal, past performance and investment consultants' advice. However, since expected future performance is not a good predictor of actual future performance, the observed tendency of plan sponsors not to act on their own expectations, or do so only modestly, does not necessarily have costly implications for ultimate investors.

\section{Conclusion}

Using survey data for 1999-2011 we analyze the views of plan sponsors on their asset managers. These views include judgments about asset managers' past and future performance, as well as about non-performance factors including the business processes of their asset managers, the quality of their personnel and their service delivery. We explore how performance and nonperformance factors interact in plan sponsors' survey responses, and how these relate to the flow of funds into the same asset managers.

Consistent with the view, widespread in the mutual fund literature, that investors extrapolate from past performance, we find that the future performance expected of institutional asset managers is driven largely by past performance. However, to the extent that the two performance measures are distinct, it is past performance that is the main determinant of asset flows and, once we control for past performance, expected future performance has little explanatory power over them. We also find that flows are strongly influenced by investment consultants' recommendations, and that this influence goes beyond the impact those recommendations may have on plan sponsors' expectations. These two findings suggest that that investors are not acting fully on their own expectations when making their asset allocation decisions. 
These results shed light on decision making by plan sponsors, in that they suggest separate roles for behavioral and agency effects. The apparent tendency for plan sponsors, when forming their expectations, to extrapolate from past performance and rely on soft factors when neither of these is informative about future performance (except, perhaps, over periods too short to exploit) appears irrational. By contrast, the fact plan sponsors do not act on their own expectations, or do so only marginally, when making investment decisions is consistent with agency rather than behavioral effects on the part of plan sponsors. A behavioral explanation for this would require us to believe that plan sponsors take the trouble to form expectations about the future but then, unwittingly, fail to act on those expectations. It seems more likely that their actions are at variance with their own expectations because they feel that past performance and consultants' recommendations are a more defensible explanation for their decisions to their the superiors and other stakeholders.

Agency conflicts have been the subject of a number of recent papers on defined-benefit pensions. Rauh (2009) uses survey data to explore the allocation of assets in corporate pension funds as part of the wider risk management strategy of the sponsoring firm. Cocco and Volpin (2007) find that trustees appointed by the sponsoring company, as opposed to external trustees, are associated with lower returns to pension funds, while Phan and Hegde (2013) conclude that good corporate governance in general leads to higher investment returns. Our results, which are consistent with plan sponsor officials being subject to conflicts in asset manager selection, add to the body of empirical evidence of agency problems in institutional fund management. They highlight another type of conflict affecting this decision: plan directors, when making asset allocation decisions, will likely have in mind not just the interests of plan participants, or of the shareholders of sponsoring firm, but their own interests and career concerns as well. 


\section{References}

Andrich, D. “A Rating Formulation for Ordered Response Categories." Psychometrika, 43 (1978), 561-573.

Armantier, O.; W. Bruine de Bruin; G. Topa; W. van der Klaauw; and B. Zafar. "Inflation Expectations and Behavior: Do Survey Respondents Act on Their Beliefs?” Federal Reserve Bank of New York Staff Report no. 509 (2011).

Badrinath, S.; G. Gay; and J. Kale. "Patterns of Institutional Investment, Prudence, and the Managerial Safety-Net Hypothesis.” The Journal of Risk and Insurance, 56 (1989), 605629.

Basu, S., and S. Markov. "Loss Function Assumptions in Rational Expectations Tests on Financial Analysts' Earnings Forecasts.” Journal of Accounting and Economics, 38 (2004), 171-203.

Berk, J. B., and R. C. Green. "Mutual Fund Flows and Performance in Rational Markets." Journal of Political Economy, 112 (2004), 1269-1295.

Berk, J. B., and I. Tonks, "Return Persistence and Fund Flows in the Worst Performing Mutual Funds" National Bureau of Economic Research W13042 (2007).

Busse, J.; A. Goyal; and S. Wahal. "Performance and Persistence in Institutional Investment Management." Journal of Finance, 65 (2010), 765-790.

Cameron, A. C.; J. B. Gelbach; and D. L. Miller. "Robust Inference with Multiway Clustering." Journal of Business \& Economic Statistics, 29 (2011), 238-249.

Carhart, M. “On Persistence in Mutual Fund Performance.” Journal of Finance, 52 (1997), $57-$ 82. 
Carroll, C. D. "Macroeconomic Expectations of Households and Professional Forecasters." Quarterly Journal of Economics, 118 (2003), 269-298.

Chernov, M., and P. Mueller. "The Term Structure of Inflation Expectations." Journal of Financial Economics, 106 (2012), 367-394.

Chevalier, J., and G. Ellison. "Risk Taking by Mutual Funds as a Response to Incentives." Journal of Political Economy, 105 (1997), 1167-1200.

Cocco, J. F.; and P. F. Volpin. "Corporate Governance of Pension Plans: The U.K. Evidence." Financial Analysts Journal, 63 (2007), 70-83.

De Bondt, W. F. M. "Betting on Trends: Intuitive Forecasts of Financial Risk and Return." International Journal of forecasting, 9 (1993), 355-371.

Del Guercio, D. "The Distorting Effect of the Prudent-Man Laws on Institutional Equity investments." Journal of Financial Economics, 40 (1996), 31-62.

Del Guercio, D., and J. Reuter. "Mutual Fund Performance and the Incentive to Generate Alpha," Journal of Finance, 69 (2014), 1673-1704.

Del Guercio, D., and P. Tkac. "The Determinants of the Flow of Funds of Managed Portfolios: Mutual Funds Versus Pension Funds.” Journal of Financial and Quantitative Analysis, 37 (2002), 523-557.

Dorfman, J. “Analysts Devote More Time to Selling as Firms Keep Scorecard on Performance.” Wall Street Journal, 29 (1991).

Dugar, A., and S. Nathan. "The Effect of Investment Banking Relationships on Financial Analysts' Earnings Forecasts and Investment Recommendations." Contemporary Accounting Research, 12 (1995), 131-160. 
Figlewski, S., and Wachtel, P. "Rational Expectations, Informational Efficiency and Tests Using Survey Data.” Review of Economics and Statistics, 65 (1983), 529-531.

Fama, E., and K. French. "Common Risk Factors in the Returns on Stocks and Bonds." Journal of Financial Economics, 33 (1993), 3-56.

Francis, J., and D. Philbrick. "Analysts' Decisions as Products of a Multi-Task Environment.” Journal of Accounting Research (1993), 216-230.

Goetzmann, W. N., and N. Peles. “Cognitive Dissonance and Mutual Fund Investors.” Journal of Financial Research, 20 (1997), 145-158.

Goriaev, A.; T. Nijman; and B. Werker. "Performance Information Dissemination in the Mutual Fund Industry.” Journal of Financial Markets, 11 (2008), 144-159.

Goyal, A., and S. Wahal. "The Selection and Termination of Investment Management Firms by Plan Sponsors.” Journal of Finance, 63 (2008), 1805-1847.

Greenwood, R., and A. Shleifer. "Expectations of Returns and Expected Returns.” No. w18686. National Bureau of Economic Research (2013).

Hong, H.; J. D. Kubik; and A. Solomon. 'Security Analysts' Career Concerns and Herding of Earnings Forecasts.” The RAND Journal of Economics, 31 (2000), 121-144.

Ippolito, R. A. "Consumer Reaction to Measures of Poor Quality: Evidence from the Mutual Fund Industry.” Journal of Law and Economics, 35 (1992), 45-70.

Jenkinson, T.; H. Jones; and J. Martinez. 'Picking Winners? Investment Consultants' Recommendations of Fund Managers.” Journal of Finance (forthcoming).

Kahneman, D.; P. Slovic; and A. Tversky (eds). Judgment under Uncertainty: Heuristics and Biases. Cambridge: Cambridge University Press: University Press (1982). 
Keane, M., and D. Runkle. "Testing the Rationality of Price Forecasts: New Evidence from Panel Data.” American Economic Review, 80 (1990), 714-735.

Lakonishok, J.; A. Shleifer; R. Thaler; and R. Vishny. "Window Dressing by Pension Fund Managers.” American Economic Review Papers and Proceedings, 81 (1991), 227-231.

Lakonishok, J.; A. Shleifer; and R. Vishny. The Structure and Performance of the Money Management Industry, Brookings Papers on Economic Activity (1992), 339-391.

Lakonishok, J.; A. Shleifer; and R. Vishny. "Contrarian Investment, Extrapolation and Risk." Journal of Finance, 49 (1994), 1541-1578.

Lamont, O. "Discussion of 'Perspectives on Behavioral Finance: Does Irrationality Disappear with Wealth? Evidence from Expectations and Actions' by Annette Vissing-Jorgensen.” In NBER Macroeconomics Annual 2003, edited by M. Gertler and K. Rogoff (2003).

Leduc, S.; K. Sill; and T. Stark. "Self-Fulfilling Expectations and the Inflation of the 1970s: Evidence from the Livingston Survey.” Journal of Monetary Economics, 54 (2007), 433 57.

Lin, H. and M. McNichols. "Underwriting Relationships, Analysts' Earnings Forecasts and Investment Recommendations.” Journal of Accounting and Economics, 25 (1998), 10127.

Lynch, A., and D. Musto. "How Investors Interpret Past Fund Returns.” Journal of Finance, 58 (2003), 2033-2058.

Petersen, M. A. "Estimating Standard Errors in Finance Panel Data Sets: Comparing Approaches." Review of Financial Studies, 22 (2009), 435-480. 
Phan, H. V., and S. P. Hegde. "Corporate Governance and Risk Taking in Pension Plans: Evidence from Defined Benefit Asset Allocations." Journal of Financial and Quantitative Analysis, 48 (2013), 919-946.

Ramnath, S.; S. Rock; and P. Shane. "The Financial Analyst Forecasting Literature: A Taxonomy with Suggestions for Further Research.” International Journal of Forecasting, 24 (2008), 34-75.

Rauh, J. D. "Risk Shifting Versus Risk Management: Investment Policy in Corporate Pension Plans.” Review of Financial Studies, 22 (2009), 2687-2733.

Rogers, W. "Regression Standard Errors in Clustered Samples.” Stata Technical Bulletin, 13 (2993), 19-23.

Sharpe, W. F. "Capital Asset Prices: A Theory of Market Equilibrium under Conditions of Risk.” Journal of Finance, 19 (1964), 425-442.

Sirri, E. R., and P. Tufano. "Costly Search and Mutual Fund Flows.” Journal of Finance, 53 (1998), 1589-1622.

White, H. "A Heteroskedasticity-Consistent Covariance Matrix Estimator and a Direct Test of Heteroscedasticity." Econometrica, 48 (1980), 817-838. 


\section{Table 1}

\section{Greenwich Associates Plan Sponsors Survey Summary Statistics}

The table shows, for each variable included in the 2011 Greenwich Associates survey of plan sponsors: the number of respondents to the survey that provided answers about that variable; the number of evaluations (each plan sponsor typically evaluates more than one asset manager); the mean and standard deviation of the individual scores; and the $p$-values of two tests of no differences in scores among asset managers: the $F$-test of identical means, and the Kruskal-Wallis test. * and ** indicate statistical significance at the $5 \%$ and $1 \%$ levels, respectively.

\begin{tabular}{|c|c|c|c|c|c|c|}
\hline \multirow[b]{2}{*}{ GA Variable } & \multirow{2}{*}{$\begin{array}{c}\text { No. of } \\
\text { Respondents }\end{array}$} & \multirow{2}{*}{$\begin{array}{c}\text { No. of } \\
\text { Evaluations }\end{array}$} & \multirow{2}{*}{$\begin{array}{l}\text { Mean } \\
\text { Score }\end{array}$} & \multirow{2}{*}{$\begin{array}{l}\text { Std. } \\
\text { Dev. }\end{array}$} & \multicolumn{2}{|c|}{$\begin{array}{l}\text { Tests of No Difference } \\
\text { in Scores among Asset } \\
\text { Mgrs. }\end{array}$} \\
\hline & & & & & $\begin{array}{c}F \text {-test ( } p \text { - } \\
\text { value) }\end{array}$ & $\begin{array}{l}\text { Kruskal- } \\
\text { Wallis } \\
\text { test ( } p \text { - } \\
\text { value) }\end{array}$ \\
\hline Expected Future Performance & 761 & 3,000 & 4.00 & 0.75 & $0.0000 * *$ & $0.0001 * *$ \\
\hline Reported Past Performance & 808 & 3,143 & 3.81 & 0.88 & $0.0000 * *$ & $0.0001 * *$ \\
\hline Soft Investment Factors & & & & & & \\
\hline Consistent Inv. Philosophy & 808 & 3,155 & 4.24 & 0.70 & $0.0000 * *$ & $0.0001 * *$ \\
\hline Clear Decision Making & 785 & 3,048 & 4.18 & 0.71 & $0.0000 * *$ & $0.0001 * *$ \\
\hline Capable Inv. Professionals & 797 & 3,082 & 4.24 & 0.69 & $0.0000^{* *}$ & $0.0001 * *$ \\
\hline Service Factors & & & & & & \\
\hline Understanding of Objectives & 824 & 3,552 & 4.12 & 0.79 & $0.0109 *$ & $0.0090 * *$ \\
\hline Relationship Manager & 828 & 3,508 & 4.11 & 0.78 & $0.0005 * *$ & $0.0016 * *$ \\
\hline Credibility & 777 & 3,326 & 4.12 & 0.79 & $0.0000^{* *}$ & $0.0001 * *$ \\
\hline Useful Written Reports & 782 & 3,337 & 3.90 & 0.74 & $0.0092 * *$ & $0.0315^{*}$ \\
\hline Useful Formal Meetings & 733 & 3,094 & 4.02 & 0.75 & $0.0095^{* *}$ & $0.032 *$ \\
\hline Useful Informal Meetings & 691 & 2,893 & 4.03 & 0.75 & $0.0133^{*}$ & $0.0235^{*}$ \\
\hline
\end{tabular}


Table 2

\section{Sample Statistics}

The table shows the total number of U.S. domestic equity asset managers in our sample each year. It also shows the number of asset managers which reported assets under management (AUM) data, as well as their mean and median assets. Mean and median assets under management are in millions of U.S. dollars.

\begin{tabular}{lccccc}
\hline \hline & $\begin{array}{c}\text { No. of Asset } \\
\text { Managers in } \\
\text { Sample }\end{array}$ & & & & \\
& & & & & \\
& & No. & \% of Total & $\begin{array}{c}\text { Mean AUM } \\
\text { \$Million }\end{array}$ & $\begin{array}{c}\text { Median AUM } \\
\text { \$Million }\end{array}$ \\
\cline { 3 - 6 } & & & $34 \%$ & 10,687 & 6,516 \\
2000 & 85 & 41 & $48 \%$ & 12,387 & 3,805 \\
2001 & 86 & 65 & $76 \%$ & 17,169 & 8,983 \\
2002 & 109 & 95 & $87 \%$ & 16,324 & 7,223 \\
2003 & 101 & 92 & $91 \%$ & 15,089 & 7,829 \\
2004 & 115 & 102 & $89 \%$ & 19,264 & 9,848 \\
2005 & 128 & 116 & $91 \%$ & 21,014 & 10,130 \\
2006 & 130 & 123 & $95 \%$ & 23,567 & 11,041 \\
2007 & 154 & 143 & $93 \%$ & 23,909 & 9,421 \\
2008 & 170 & 152 & $89 \%$ & 22,914 & 10,051 \\
2009 & 145 & 135 & $93 \%$ & 14,791 & 7,157 \\
2010 & 161 & 148 & $92 \%$ & 16,719 & 7,312 \\
2011 & 169 & 159 & $94 \%$ & 18,085 & 8,259 \\
\hline Total & 232 & 213 & $92 \%$ & 18,891 & 4,232 \\
\hline \hline
\end{tabular}




\section{Table 3}

\section{Determinants of Expected Performance}

Table 3 reports the results of pooled time-series cross-sectional OLS regressions of expected future performance rankings on past performance (reported past performance or past excess return over benchmark), soft investment factor and service factor rankings. Expected future performance, reported past performance, past excess return over benchmark, and soft investment factor and service factor rankings are expressed using the fractional rank of each asset manager in the sample. An asset manager's fractional rank, for a given variable, represents its percentile rank relative to other asset managers in the same period, and ranges from 0 to 1 . Some regressions also include a measure of the number of investment consultants' recommendations received (over the total possible) by the asset manager, or its change, lagged log assets under management, and return volatility. Each column represents a separate regression. $t$-statistics based on standard errors clustered at the asset manager level are included in parentheses. $*$ and $* *$ indicate statistical significance at the $5 \%$ and $1 \%$ levels, respectively.

\begin{tabular}{|c|c|c|c|}
\hline & 1 & 2 & 3 \\
\hline REPORTED_PAST_PERF ${ }_{i, t}$ & $\begin{array}{l}0.47 * * \\
(17.72)\end{array}$ & $\begin{array}{l}0.47 * * \\
(17.43)\end{array}$ & \\
\hline PAST_EX_RET ${ }_{i, t}$ & & & $\begin{array}{c}0.18 * * \\
(6.38)\end{array}$ \\
\hline SOFT_INV_FACTORS $_{i, t}$ & $\begin{array}{l}0.32 * * \\
(10.43)\end{array}$ & $\begin{array}{l}0.32 * * \\
(10.40)\end{array}$ & $\begin{array}{l}0.56 * * \\
(19.05)\end{array}$ \\
\hline SERVICE_FACTORS $_{i, t}$ & $\begin{array}{l}0.10^{* * *} \\
(3.35)\end{array}$ & $\begin{array}{c}0.10^{* * *} \\
(3.38)\end{array}$ & $\begin{array}{c}0.11 * * \\
(3.66)\end{array}$ \\
\hline CONSULTANTS_RECS $_{i, t}$ & $\begin{array}{c}0.20 \\
(1.84)\end{array}$ & & $\begin{array}{c}0.25 \\
(1.79)\end{array}$ \\
\hline$\triangle$ CONSULTANTS_RECS ${ }_{i, t}$ & & $\begin{array}{c}0.29 \\
(1.66)\end{array}$ & $\begin{array}{l}0.44 * \\
(2.09)\end{array}$ \\
\hline $\mathrm{TNA}_{i, t-1}$ & $\begin{array}{l}-0.00 \\
(-0.42)\end{array}$ & $\begin{array}{c}0.00 \\
(0.06)\end{array}$ & $\begin{array}{c}-0.01 \\
(-1.33)\end{array}$ \\
\hline RETURN_VOL $_{i, t-1}$ & $\begin{array}{c}0.02 \\
(0.19)\end{array}$ & $\begin{array}{c}0.03 \\
(0.21)\end{array}$ & $\begin{array}{c}-0.07 \\
(-0.51)\end{array}$ \\
\hline INTERCEPT & $\begin{array}{c}0.06 \\
(1.29)\end{array}$ & $\begin{array}{c}0.05 \\
(1.02)\end{array}$ & $\begin{array}{l}0.15^{*} \\
(2.57)\end{array}$ \\
\hline$R^{2}$ & 0.62 & 0.63 & 0.51 \\
\hline No. of obs. & 1,390 & 1,364 & 1,339 \\
\hline
\end{tabular}




\section{Table 4}

\section{Information Content of Expected Future Performance Rankings}

Panel A of Table 4 reports the results of pooled time-series cross-sectional OLS regressions of future excess return rankings $\left(\mathrm{PERF}_{i, t+1}\right)$ on reported past performance (alternatively past excess returns), soft investment factor and service factor rankings. Panel B adds expected future performance rankings as a regressor. $\mathrm{PERF}_{i, t+l}$ are computed for the one-year period starting one week after the last fielding date of the survey. PAST_EX_RET ${ }_{i, t}$ are computed for the two-year periods finishing at the end of the month preceding the first fielding date of the survey. Excess returns, expected future performance, reported past performance, and soft investment factor and service factor rankings are expressed using the fractional rank of each asset manager in the sample. An asset manager's fractional rank, for a given variable, represents its percentile rank relative to other asset managers in the same period, and ranges from 0 to 1 . All regressions also include a measure of the number of investment consultants' recommendations received (over the total possible) by the asset manager, lagged log assets under management, and return volatility. Each column represents a separate regression. $t$-statistics based on standard errors clustered at the asset manager level are included in parentheses. * and ** indicate statistical significance at the 5\% and $1 \%$ levels, respectively.

\begin{tabular}{|c|c|c|c|c|}
\hline & \multicolumn{2}{|c|}{$\begin{array}{l}\text { Panel A. Excluding } \\
\text { Expected Future } \\
\text { Performance }\end{array}$} & \multicolumn{2}{|c|}{$\begin{array}{c}\text { Panel B. Including } \\
\text { Expected Future } \\
\text { Performance }\end{array}$} \\
\hline & 1 & 2 & 3 & 4 \\
\hline EXPECTED_PERF $_{i, t}$ & & & $\begin{array}{c}-0.04 \\
(-0.98)\end{array}$ & $\begin{array}{c}-0.03 \\
(-0.73)\end{array}$ \\
\hline REPORTED_PAST_PERF $_{i, t}$ & $\begin{array}{c}0.03 \\
(0.89)\end{array}$ & & $\begin{array}{c}0.05 \\
(1.33)\end{array}$ & \\
\hline PAST_EX_RET ${ }_{i, t}$ & & $\begin{array}{c}0.05 \\
(1.64)\end{array}$ & & $\begin{array}{c}0.05 \\
(1.80)\end{array}$ \\
\hline SOFT_INV_FACTORS $_{i, t}$ & $\begin{array}{c}-0.06 \\
(-1.64)\end{array}$ & $\begin{array}{c}-0.06 \\
(-1.90)\end{array}$ & $\begin{array}{c}-0.05 \\
(-1.20)\end{array}$ & $\begin{array}{c}-0.05 \\
(-1.20)\end{array}$ \\
\hline SERVICE_FACTORS $_{i, t}$ & $\begin{array}{c}0.05 \\
(1.34)\end{array}$ & $\begin{array}{c}0.05 \\
(1.48)\end{array}$ & $\begin{array}{c}0.05 \\
(1.40)\end{array}$ & $\begin{array}{c}0.05 \\
(1.53)\end{array}$ \\
\hline CONSULTANTS_RECS $_{i, t}$ & $\begin{array}{c}-0.05 \\
(-0.28)\end{array}$ & $\begin{array}{c}-0.04 \\
(-0.24)\end{array}$ & $\begin{array}{c}-0.04 \\
(-0.22)\end{array}$ & $\begin{array}{c}-0.03 \\
(-0.19)\end{array}$ \\
\hline $\mathrm{TNA}_{i, t-1}$ & $\begin{array}{c}-0.00 \\
(-0.82)\end{array}$ & $\begin{array}{c}-0.00 \\
(-0.83)\end{array}$ & $\begin{array}{c}-0.00 \\
(-0.85)\end{array}$ & $\begin{array}{c}-0.00 \\
(-0.87)\end{array}$ \\
\hline RETURN_VOL $_{i, t-1}$ & $\begin{array}{c}0.02 \\
(0.11)\end{array}$ & $\begin{array}{c}0.03 \\
(0.20)\end{array}$ & $\begin{array}{c}0.02 \\
(0.12)\end{array}$ & $\begin{array}{c}0.03 \\
(0.21)\end{array}$ \\
\hline INTERCEPT & $\begin{array}{l}0.50 * * \\
(10.41)\end{array}$ & $\begin{array}{c}0.48 * * \\
(9.95)\end{array}$ & $\begin{array}{l}0.50 * * \\
(10.44)\end{array}$ & $\begin{array}{c}0.49 * * \\
(9.98)\end{array}$ \\
\hline$R^{2}$ & 0.00 & 0.01 & 0.00 & 0.01 \\
\hline No. of obs. & 1,196 & 1,193 & 1,196 & 1,193 \\
\hline
\end{tabular}




\section{Table 5}

\section{Effect of Past and Expected Performance, Soft Investment Factors, Service Factors and Consultants' Recommendations on Asset Flows}

Table 5 reports the results of pooled time-series cross-sectional regressions of asset managers' yearly asset flows on lagged past, and expected future, investment performance, variables measuring soft investment factors and service factors, and investment consultants' recommendations. The sample includes asset managers' U.S. active equity products only. These products are aggregated into a single observation for each asset manager-year. Asset flows are expressed as percentages of total assets under management at the end of the previous year. Past performance is proxied using reported past performance (in the survey) or the excess return computed over the two-year period finishing at the end of the month preceding the first fielding date of the previous year survey. Past and expected future performance, soft investment factors, and service factors are expressed using the fractional rank of each asset manager in the sample. An asset manager's fractional rank, for a given variable, represents its percentile rank relative to other asset managers in the same period, and ranges from 0 to 1 . The change in consultants' recommendations is the change in the percentage of short list recommendations received over the total possible. All regressions also include a lagged measure of log assets under management, return volatility, and a full set of time dummies (which are not reported in the table). Each column represents a separate regression. $t$ statistics based on standard errors clustered at the product level are included in parentheses. * and ** indicate statistical significance at the $5 \%$ and $1 \%$ levels, respectively. 


\begin{tabular}{|c|c|c|c|c|}
\hline & $\overline{1}$ & 2 & 3 & 4 \\
\hline EXPECTED_PERF $_{i, t-1}$ & $\begin{array}{l}-0.01 \\
(-0.25)\end{array}$ & $\begin{array}{c}-0.05 \\
(-1.16)\end{array}$ & $\begin{array}{l}0.10 * * \\
(3.19)\end{array}$ & $\begin{array}{l}0.06^{*} \\
(2.07)\end{array}$ \\
\hline EXPECTED_PERF $_{i, t-2}$ & & $\begin{array}{c}0.06 \\
(1.40)\end{array}$ & & $\begin{array}{c}0.06 \\
(1.76)\end{array}$ \\
\hline REPORTED_PAST_PERF $F_{i, t-1}$ & $\begin{array}{c}0.31 * * \\
(7.93)\end{array}$ & $\begin{array}{c}0.31 * * \\
(6.91)\end{array}$ & & \\
\hline REPORTED_PAST_PERF $F_{i, t-2}$ & & $\begin{array}{c}0.02 \\
(0.68)\end{array}$ & & \\
\hline PAST_EX_RET $T_{i, t-1}$ & & & $\begin{array}{l}0.31 * * \\
(10.88)\end{array}$ & $\begin{array}{c}0.27 * * \\
(7.64)\end{array}$ \\
\hline PAST_EX_RET ${ }_{i, t-2}$ & & & & $\begin{array}{c}0.04 \\
(1.38)\end{array}$ \\
\hline SOFT_INV_FACTORS ${ }_{i, t-1}$ & $\begin{array}{l}-0.08 \\
(-1.74)\end{array}$ & $\begin{array}{l}-0.05 \\
(-1.20)\end{array}$ & $\begin{array}{c}-0.01 \\
(-0.27)\end{array}$ & $\begin{array}{c}0.01 \\
(0.36)\end{array}$ \\
\hline SOFT_INV_FACTORS $S_{i, t-2}$ & & $\begin{array}{l}-0.05 \\
(-0.82)\end{array}$ & & $\begin{array}{c}-0.03 \\
(-0.54)\end{array}$ \\
\hline SERVICE_FACTORS $_{i, t-1}$ & $\begin{array}{c}0.03 \\
(0.72)\end{array}$ & $\begin{array}{c}0.01 \\
(0.32)\end{array}$ & $\begin{array}{c}0.00 \\
(0.14)\end{array}$ & $\begin{array}{c}-0.01 \\
(-0.45)\end{array}$ \\
\hline SERVICE_FACTORS $_{i, t-2}$ & & $\begin{array}{c}0.01 \\
(0.30)\end{array}$ & & $\begin{array}{c}0.01 \\
(0.34)\end{array}$ \\
\hline$\triangle$ CONSULTANTS_RECS ${ }_{i, t-1}$ & $\begin{array}{c}0.68 * * \\
(3.79)\end{array}$ & $\begin{array}{l}0.54 * * \\
(2.73)\end{array}$ & $\begin{array}{c}0.57 * * \\
(3.17)\end{array}$ & $\begin{array}{l}0.47^{*} \\
(2.57)\end{array}$ \\
\hline $\mathrm{TNA}_{i, t-1}$ & $\begin{array}{l}-0.01 \\
(-1.46)\end{array}$ & $\begin{array}{l}-0.01 \\
(-1.23)\end{array}$ & $\begin{array}{l}-0.00 \\
(-0.72)\end{array}$ & $\begin{array}{c}-0.00 \\
(-0.18)\end{array}$ \\
\hline RETURN_VOL $_{i, t-1}$ & $\begin{array}{c}-0.38 \\
(-0.89)\end{array}$ & $\begin{array}{c}-0.86 \\
(-1.92)\end{array}$ & $\begin{array}{c}-0.72 \\
(-1.75)\end{array}$ & $\begin{array}{c}-1.15^{* *} \\
(-2.65)\end{array}$ \\
\hline Year Dummies & Yes & Yes & Yes & Yes \\
\hline$R^{2}$ & 0.15 & 0.17 & 0.18 & 0.19 \\
\hline No. of obs. & 1,169 & 1,044 & 1,157 & 1,035 \\
\hline
\end{tabular}




\section{Table 6}

\section{The Effect of Investment Performance and Service Quality on Asset Flows: Nonlinearities}

Table 6 reports the results of pooled time-series cross-sectional regressions of asset managers' yearly asset flows on lagged past, and expected future, investment performance, variables measuring soft investment factors and service factors, and investment consultants' recommendations. Asset flows are expressed as percentages of total assets under management at the end of the previous year. Past and expected future performance, soft investment factors and service factors are expressed using the fractional rank of each asset manager in the sample. To test for nonlinearities in the flow-performance/service quality relation we estimate separate lagged performance and service factor coefficients for those asset managers ranked above and below a given threshold (defined by the 33rd percentile of service quality and past performance). PP and SF stand for past performance and service factors, respectively. The change in consultants' recommendations is the change in the percentage of short list recommendations received over the total possible. All regressions also include a lagged measure of log assets under management, return volatility, and a full set of time dummies (which are not reported in the table). Each column represents a separate regression. t-statistics based on standard errors clustered at the product level are included in parentheses. ${ }^{*}$ and $* *$ indicate statistical significance at the $5 \%$ and $1 \%$ levels, respectively. 


\begin{tabular}{|c|c|c|c|}
\hline & $\overline{1.1}$ & 2 & 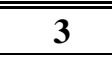 \\
\hline EXPECTED_PERF $F_{i, t-1}$ & $\begin{array}{l}-0.01 \\
(-0.31)\end{array}$ & $\begin{array}{c}-0.01 \\
(-0.32)\end{array}$ & $\begin{array}{c}-0.01 \\
(-0.28)\end{array}$ \\
\hline REPORTED_PAST_PERF ${ }_{i, t-1}$ & & $\begin{array}{l}0.32 * * \\
(7.99)\end{array}$ & $\begin{array}{r}0.33 * * \\
(7.94)\end{array}$ \\
\hline REPORTED_PAST_PERF $\times \mathrm{I}(\mathrm{PP}<\text { threshold })_{i, t-1}$ & $\begin{array}{c}0.49 * * \\
(3.83)\end{array}$ & & \\
\hline REPORTED_PAST_PERF $\times$ I $(\mathrm{PP}>\text { threshold })_{i, t-1}$ & $\begin{array}{c}0.26^{* *} \\
(5.35)\end{array}$ & & \\
\hline SOFT_INV_FACTORS $S_{i, t-1}$ & $\begin{array}{l}-0.08 \\
(-1.74)\end{array}$ & $\begin{array}{l}-0.08 \\
(-1.78)\end{array}$ & $\begin{array}{l}-0.08 \\
(-1.76)\end{array}$ \\
\hline SERVICE_FACTORS $_{i, t-1}$ & $\begin{array}{c}0.02 \\
(0.67)\end{array}$ & & \\
\hline SERVICE_FACTORS $\times \mathrm{I}(\mathrm{SF}<\text { threshold })_{i, t-1}$ & & $\begin{array}{l}0.26^{*} \\
(2.15)\end{array}$ & \\
\hline SERVICE_FACTORS $\times$ I $(\mathrm{SF}>\text { threshold })_{i, t-1}$ & & $\begin{array}{c}-0.04 \\
(-0.97)\end{array}$ & \\
\hline SERVICE_FACTORS $\times \mathrm{I}(\mathrm{PP}<\text { threshold })_{i, t-1}$ & & & $\begin{array}{c}0.09 \\
(1.67)\end{array}$ \\
\hline SERVICE_FACTORS $\times \mathrm{I}(\mathrm{PP}>\text { threshold })_{i, t-1}$ & & & $\begin{array}{l}0.00 \\
(0.05)\end{array}$ \\
\hline$\Delta$ CONSULTANTS_RECS $S_{i, t-1}$ & $\begin{array}{c}0.69 * * \\
(3.82)\end{array}$ & $\begin{array}{c}0.70 * * \\
(3.91)\end{array}$ & $\begin{array}{r}0.69 * * \\
(3.82)\end{array}$ \\
\hline $\mathrm{TNA}_{i, t-1}$ & $\begin{array}{l}-0.02 \\
(-1.56)\end{array}$ & $\begin{array}{l}-0.02 \\
(-1.64)\end{array}$ & $\begin{array}{l}-0.01 \\
(-1.43)\end{array}$ \\
\hline RETURN_VOL $_{i, t-1}$ & $\begin{array}{l}-0.38 \\
(-0.89)\end{array}$ & $\begin{array}{c}-0.44 \\
(-1.03)\end{array}$ & $\begin{array}{c}-0.40 \\
(-0.92)\end{array}$ \\
\hline $\begin{array}{l}\text { Test Past Perf }(+)=\text { Past Perf }(-) \\
\text { Test Serv. Fact. }(+)=\text { Serv. Fact. }(-)\end{array}$ & 0.12 & $0.03 *$ & 0.13 \\
\hline Year Dummies & Yes & Yes & Yes \\
\hline$R^{2}$ & 0.16 & 0.16 & 0.15 \\
\hline No. of obs. & 1,169 & 1,169 & 1,169 \\
\hline
\end{tabular}




\section{Internet Appendix to "Institutional Investor Expectations, Manager Performance, and Fund Flows"}

\section{Further Details on the Greenwich Associates (GA) Survey}

\section{A. The GA Survey of Plan Sponsors: Aggregation of Responses}

The value assigned to each GA factor (service or investment) in our dataset is a statistical combination of the plan sponsors' evaluations of their asset managers. GA arrives at these values by organizing all plan sponsors' responses for each program into a matrix where each column contains a question and each row contains a plan sponsor's responses to all questions about one of his asset managers. GA summarizes the scores for each individual plan sponsor-to-asset manager relationship using the Rasch model and the maximum likelihood method. ${ }^{1}$ This statistical method computes a scaled score for each relationship based upon the entire set of the plan sponsor's responses to the questions for each asset manager. Scores are then normalized, by subtracting the mean of the score distribution from each scaled score and dividing by the standard deviation of that score distribution. These normalized scores are constrained within the $(-3$ to +3$)$ range. The constrained normal scores are transformed to the GA index scale by multiplying them by the standard deviation and then adding the GA scale mean.

\footnotetext{
${ }^{1}$ The Rasch model, a special case of item response theory, is a psychometric model for analyzing categorical data. For a detailed description of this model we refer the reader to the extensive literature on the topic (e.g., Andrich, David. Rasch Models for Measurement: SAGE Publications. Vol. 68. Sage Publications (1988); or Fischer, Gerhard H., and Ivo W. Molenaar, eds. Rasch models: Foundations, Recent Developments, and Applications. Springer Science \& Business Media (2012)).
} 


\section{B. The GA Survey of Investment Consultants}

In this GA survey, investment consultants are asked to rate active fund managers on various measures of performance and service, and also to state the names of the fund managers they recommend to their clients in each of a number of investment size-style categories. As with the survey of plan sponsors, we draw on the investment consultant surveys between 1999 and 2011. Consultants respond to the questionnaires in confidence, and the responses by individual investment consultants to the GA questionnaires are not disclosed in the survey results, but rather the aggregate responses.

The main information we obtain from the surveys of investment consultants is an annual list of fund managers showing, in each size-style category, the percentage of the consultants surveyed who recommended that fund manager. According to GA, consultants are asked to recommend between four and six fund managers for each of seven different size-style categories: Large Cap Growth, Large Cap Value, Small Cap Growth, Small Cap Value, Mid Cap Growth, Mid Cap Value and Domestic Equity Core. If a fund manager manages more than one product in a given size-style category we aggregate those products into a single one, to make it correspond to the GA classification. We combine consultants' recommendations for the same asset manager's different investment size-styles to match them with plan sponsors' responses, which are given at the level of the asset class and not broken down by size-style category (see Appendix Figure I). Since we obtain our data from original documents we are confident that all recommendations are included in the database even if a product ceases to exist, or if returns are no longer reported, and so the recommendations data are free from survivorship and backfill bias. For more details see Jenkinson et al. (forthcoming). 


\section{Further Details on Combining the GA Survey and eVestment Data}

The GA plan sponsors survey, the GA investment consultants survey, and the eVestment database each provide different levels of detail. In the GA plan sponsors survey the plan sponsors evaluate each asset manager in a whole asset class; thus the responses would be in respect of, for example, Firm XYZ Active U.S. Equities. In the GA investment consultants survey the consultants list their recommendations of asset managers by size-style category, that is, at one more level of detail than in the plan sponsors survey. Thus in our sample the recommendations of investment consultants relate to sub-categories within the asset class of U.S. Active Equities, e.g. Firm XYZ U.S. Active Equities Large Cap Growth, Firm XYZ U.S. Equities Small Cap Value, etc. Finally, the eVestment database provides AUM and performance data at a more detailed level still, namely at the level of the individual fund; for example, if Firm XYZ manages three funds in the size-style category U.S. Active Equities Large Cap growth, the data for these funds is shown separately in the eVestment database. To match the eVestment data with investment consultants' recommendations in the GA survey, we aggregate the eVestment data for all funds within a size-style category. To match the eVestment data with plan sponsors' survey responses, we aggregate the eVestment data for all funds in an asset class. The various levels of detail in the GA surveys and in the eVestment database are depicted in Appendix Figure 1.

It should be noted that the flows data which we derive from the eVestment database reflects the total flows into and out of the funds recorded in those databases, and not merely the flows originating with the plan sponsors responding to the GA survey. 


\section{Appendix Tables and Figures}

In Appendix Tables 1 to 5 we extend the analysis of Tables 3 to 5 in the paper by considering a wider set of past performance measures (Fama-French three-factor alphas as well as excess returns over benchmarks) and performance measurement horizons (one, two, and three year horizons). The analysis confirms our main findings: whatever benchmark of past performance is chosen, past performance is a significant driver of expectations of future performance, but those expectations have at best a second-order influence on flows. ${ }^{2}$

Appendix Table 1 What drives expectations of future performance. This extends the analysis of Table 3 in the paper by using Fama-French three factors alphas to proxy for past performance.

Appendix Table 2 The relation between future performance and past performance, soft investment factors and service factors.

Appendix Table 3 Is there any information in expected future performance rankings?

These tables extend the analysis of Table 4 in the paper by showing results using one- and two-year excess returns and three-factor alphas.

Appendix Table 4 Effect of past and expected performance, soft investment factors, service factors and consultants' recommendations on asset flows. Appendix Table 5 Effect of past and expected performance, soft investment factors,

\footnotetext{
${ }^{2}$ Although not reported, similar results also obtain if we use one-factor (CAPM) alphas or four-factor (FamaFrench-Carhart) alphas. The same happens if we remove 1999 to 2001 observations from the sample.
} 
service factors and consultants' recommendations on asset flows Additional past performance measures.

These tables expand on the analysis of Table 5 of the paper by providing a finer breakdown of service quality factors (Appendix Table 4) and controlling for a more complete set of actual past performance measures (past one or two-year 3-factor alphas or past one-year excess returns over benchmarks) (Appendix Table 5).

\section{Appendix Table 6}

The effect of investment performance and service quality on asset flows: non-linearities. In Appendix Table 6 we extend the analysis of Table 6 of the paper by evaluating the slopes of past performance and service quality above (+) and below (-) the $50^{\text {th }}$ percentile of past performance or service quality, in addition to the $33^{\text {rd }}$ percentile threshold reported in the paper.

\section{Appendix Table 7}

\section{Actual versus reported past performance and asset flows.}

In Appendix Table 7 we include together measures of reported past performance (survey) and past excess returns over selected benchmarks and 3-factor alphas (variables built from eVestment data) as regressors. Although there is a high degree of correlation between these variables (as we would expect), they are still different: not everybody thinks of performance as being equivalent to excess returns or 3-factor alphas (over the horizons that we measure them). It is, however, reassuring to see that even when used together in a regression framework to explain 
flows, reported past performance (from the survey) is still a highly significant predictor of future flows.

\section{Appendix Figure 1}

\section{Combined Sample: Level of Analysis}

In Appendix Figure 1 we describe the level at which each of the variables used in our analysis is available: plan sponsors' responses about past and expected future performance as well as service and investment factors, investment consultants' recommendations, and returns and assets under management. 


\section{Appendix Table 1 \\ Determinants of Expectations of Future Performance}

Appendix Table 1 reports the results of pooled time-series cross-sectional OLS regressions of expected future performance rankings on reported past performance (alternatively past excess return over benchmark or Fama-French 3-factor alpha), soft investment factor and service factor rankings. Expected future performance, reported past performance, past excess return over benchmark, 3 -factor alpha, and soft investment factor and service factor rankings are expressed using the fractional rank of each asset manager in the sample. An asset manager's fractional rank, for a given variable, represents its percentile rank relative to other asset managers in the same period, and ranges from zero to one. Some regressions also include a measure of the number of investment consultants' recommendations received (over the total possible) by the asset manager, or its change, lagged log assets under management, and return volatility. Each column represents a separate regression. $t$-statistics based on standard errors clustered at the asset manager level are included in parenthesis. $*$ and $* *$ indicate statistical significance at the $5 \%$ and $1 \%$ levels, respectively.

\begin{tabular}{|c|c|c|c|c|c|c|}
\hline & 1 & 2 & 3 & 4 & 5 & 6 \\
\hline REPORTED_PAST_PERF ${ }_{i, t}$ & $\begin{array}{l}0.49 * * \\
(20.11)\end{array}$ & $\begin{array}{l}0.47 * * \\
(17.72)\end{array}$ & $\begin{array}{l}0.47 * * \\
(17.43)\end{array}$ & $\begin{array}{l}0.47 * * \\
(17.38)\end{array}$ & & \\
\hline PAST_EX_RET ${ }_{i, t}$ & & & & & $\begin{array}{c}0.18 * * \\
(6.38)\end{array}$ & \\
\hline PAST_3F_ALPHA ${ }_{i, t}$ & & & & & & $\begin{array}{c}0.15^{\text {** }} \\
(5.30)\end{array}$ \\
\hline SOFT_INV_FACTORS ${ }_{i, t}$ & $\begin{array}{l}0.32 * * \\
(10.93)\end{array}$ & $\begin{array}{l}0.32 * * \\
(10.43)\end{array}$ & $\begin{array}{l}0.32 * * \\
(10.40)\end{array}$ & $\begin{array}{l}0.32 * * \\
(10.26)\end{array}$ & $\begin{array}{l}0.56^{* *} \\
(19.05)\end{array}$ & $\begin{array}{l}0.57^{* *} \\
(19.52)\end{array}$ \\
\hline SERVICE_FACTORS $_{i, t}$ & $\begin{array}{r}0.08 * * \\
(2.81)\end{array}$ & $\begin{array}{c}0.10^{* *} \\
(3.35)\end{array}$ & $\begin{array}{c}0.10^{* *} \\
(3.38)\end{array}$ & $\begin{array}{c}0.09 * * \\
(3.35)\end{array}$ & $\begin{array}{c}0.11^{* *} \\
(3.66)\end{array}$ & $\begin{array}{c}0.11^{* *} \\
(3.67)\end{array}$ \\
\hline CONSULTANTS_RECS ${ }_{i, t}$ & & $\begin{array}{c}0.20 \\
(1.84)\end{array}$ & & $\begin{array}{c}0.16 \\
(1.46)\end{array}$ & $\begin{array}{c}0.25 \\
(1.79)\end{array}$ & $\begin{array}{c}0.24 \\
(1.71)\end{array}$ \\
\hline$\Delta$ CONSULTANTS_RECS ${ }_{i, t}$ & & & $\begin{array}{c}0.29 \\
(1.66)\end{array}$ & $\begin{array}{c}0.21 \\
(1.15)\end{array}$ & $\begin{array}{l}0.44^{*} \\
(2.09)\end{array}$ & $\begin{array}{l}0.52^{*} \\
(2.44)\end{array}$ \\
\hline $\mathrm{TNA}_{i, t-1}$ & & $\begin{array}{c}-0.00 \\
(-0.42)\end{array}$ & $\begin{array}{c}0.00 \\
(0.06)\end{array}$ & $\begin{array}{c}-0.00 \\
(-0.35)\end{array}$ & $\begin{array}{c}-0.01 \\
(-1.33)\end{array}$ & $\begin{array}{c}-0.01 \\
(-1.46)\end{array}$ \\
\hline RETURN_VOL ${ }_{i, t-1}$ & & $\begin{array}{c}0.02 \\
(0.19)\end{array}$ & $\begin{array}{c}0.03 \\
(0.21)\end{array}$ & $\begin{array}{c}0.02 \\
(0.13)\end{array}$ & $\begin{array}{c}-0.07 \\
(-0.51)\end{array}$ & $\begin{array}{c}-0.10 \\
(-0.71)\end{array}$ \\
\hline INTERCEPT & $\begin{array}{c}0.05 * * \\
(5.62)\end{array}$ & $\begin{array}{c}0.06 \\
(1.29)\end{array}$ & $\begin{array}{c}0.05 \\
(1.02)\end{array}$ & $\begin{array}{c}0.06 \\
(1.27)\end{array}$ & $\begin{array}{l}0.15^{*} \\
(2.57)\end{array}$ & $\begin{array}{c}0.17 * * \\
(2.82)\end{array}$ \\
\hline$R^{2}$ & 0.62 & 0.62 & 0.63 & 0.63 & 0.51 & 0.50 \\
\hline No. of obs. & 1,623 & 1,390 & 1,364 & 1,364 & 1,339 & 1,339 \\
\hline
\end{tabular}




\section{Appendix Table 2}

\section{The Relation between Future Performance and Past Performance, Soft Investment Factors and Service Factors}

Appendix Table 2 reports the results of pooled time-series cross-sectional OLS regressions of future excess returns $\left(\mathrm{PERF}_{i, t+1}\right)$ or Fama-French 3 -factor alpha (3F_ALPHA ${ }_{i, t+1}$ ) rankings on reported past performance (alternatively past excess returns or Fama-French 3-factor alpha), soft investment factor and service factor rankings. PERF ${ }_{i, t+l}$ and $3 \mathrm{~F}_{-} \mathrm{ALPHA}_{i, t+l}$ are computed for the one-year and two-year periods starting one week after the last fielding date of the survey. PAST_EX_RET $i, t$ and PAST_3F_ALPHA $A_{i, t}$ are computed for the two-year periods finishing one week before the first fielding date of the survey. Excess returns, 3-factor alphas, reported past performance, and the soft investment factor and service factor rankings are expressed using the fractional rank of each asset manager in the sample. An asset manager's fractional rank, for a given variable, represents its percentile rank relative to other asset managers in the same period, and ranges from zero to one. All regressions also include a measure of the number of investment consultants' recommendations received (over the total possible) by the asset manager, lagged log assets under management, and return volatility. Each column represents a separate regression. $t$-statistics based on standard errors clustered at the asset manager level are included in parenthesis. $*$ and $* *$ indicate statistical significance at the $5 \%$ and $1 \%$ levels, respectively.

\begin{tabular}{|c|c|c|c|c|c|c|c|c|}
\hline \multirow[b]{3}{*}{ REPORTED_PAST_PERF $_{i, t}$} & \multicolumn{4}{|c|}{ Excess Return Ranking } & \multicolumn{4}{|c|}{ 3-Factor Alpha Ranking } \\
\hline & \multicolumn{2}{|c|}{ 1-Year } & \multicolumn{2}{|c|}{ 2-Year } & \multicolumn{2}{|c|}{ 1-Year } & \multicolumn{2}{|c|}{ 2-Year } \\
\hline & $\begin{array}{c}0.03 \\
(0.89)\end{array}$ & & $\begin{array}{c}-0.04 \\
(-1.19)\end{array}$ & & $\begin{array}{c}0.04 \\
(1.43)\end{array}$ & & $\begin{array}{c}-0.03 \\
(-0.70)\end{array}$ & \\
\hline PAST_EX_RET ${ }_{i, t}$ & & $\begin{array}{c}0.05 \\
(1.64)\end{array}$ & & $\begin{array}{c}-0.03 \\
(-0.91)\end{array}$ & & & & \\
\hline PAST_3F_ALPHA ${ }_{i, t}$ & & & & & & $\begin{array}{l}0.07 * \\
(2.27)\end{array}$ & & $\begin{array}{c}0.05 \\
(1.35)\end{array}$ \\
\hline SOFT_INV_FACTORS $_{i, t}$ & $\begin{array}{c}-0.06 \\
(-1.64)\end{array}$ & $\begin{array}{c}-0.06 \\
(-1.90)\end{array}$ & $\begin{array}{c}-0.03 \\
(-0.60)\end{array}$ & $\begin{array}{c}-0.05 \\
(-1.38)\end{array}$ & $\begin{array}{c}-0.03 \\
(-0.85)\end{array}$ & $\begin{array}{c}-0.03 \\
(-0.78)\end{array}$ & $\begin{array}{c}-0.03 \\
(-0.61)\end{array}$ & $\begin{array}{c}-0.05 \\
(-1.38)\end{array}$ \\
\hline SERVICE_FACTORS $_{i, t}$ & $\begin{array}{c}0.05 \\
(1.34)\end{array}$ & $\begin{array}{c}0.05 \\
(1.48)\end{array}$ & $\begin{array}{c}0.03 \\
(0.90)\end{array}$ & $\begin{array}{c}0.03 \\
(0.91)\end{array}$ & $\begin{array}{c}-0.01 \\
(-0.30)\end{array}$ & $\begin{array}{c}-0.01 \\
(-0.19)\end{array}$ & $\begin{array}{c}0.02 \\
(0.48)\end{array}$ & $\begin{array}{c}0.02 \\
(0.42)\end{array}$ \\
\hline CONSULTANTS_RECS $_{i, t}$ & $\begin{array}{c}-0.05 \\
(-0.28)\end{array}$ & $\begin{array}{c}-0.04 \\
(-0.24)\end{array}$ & $\begin{array}{c}-0.29 \\
(-1.31)\end{array}$ & $\begin{array}{c}-0.28 \\
(-1.25)\end{array}$ & $\begin{array}{c}0.02 \\
(0.10)\end{array}$ & $\begin{array}{c}0.03 \\
(0.19)\end{array}$ & $\begin{array}{c}-0.09 \\
(-0.40)\end{array}$ & $\begin{array}{c}-0.08 \\
(-0.36)\end{array}$ \\
\hline TNA $_{i, t-1}$ & $\begin{array}{c}-0.00 \\
(-0.82)\end{array}$ & $\begin{array}{c}-0.00 \\
(-0.83)\end{array}$ & $\begin{array}{c}-0.00 \\
(-0.28)\end{array}$ & $\begin{array}{c}-0.00 \\
(-0.23)\end{array}$ & $\begin{array}{c}-0.00 \\
(-0.64)\end{array}$ & $\begin{array}{c}-0.00 \\
(-0.82)\end{array}$ & $\begin{array}{c}-0.00 \\
(-0.18)\end{array}$ & $\begin{array}{c}-0.00 \\
(-0.12)\end{array}$ \\
\hline RETURN_VOL $_{i, t-1}$ & $\begin{array}{c}0.02 \\
(0.11)\end{array}$ & $\begin{array}{c}0.03 \\
(0.20)\end{array}$ & $\begin{array}{c}0.13 \\
(0.54)\end{array}$ & $\begin{array}{c}0.12 \\
(0.51)\end{array}$ & $\begin{array}{c}-0.13 \\
(-0.74)\end{array}$ & $\begin{array}{c}-0.14 \\
(-0.82)\end{array}$ & $\begin{array}{c}0.19 \\
(0.85)\end{array}$ & $\begin{array}{c}0.19 \\
(0.84)\end{array}$ \\
\hline INTERCEPT & $\begin{array}{l}0.50 * * \\
(10.41)\end{array}$ & $\begin{array}{c}0.48 * * \\
(9.95) \\
\end{array}$ & $\begin{array}{c}0.49 * * \\
(7.59)\end{array}$ & $\begin{array}{c}0.49 * * \\
(7.44)\end{array}$ & $\begin{array}{l}0.52 * * \\
(10.08)\end{array}$ & $\begin{array}{c}0.51 * * \\
(9.93)\end{array}$ & $\begin{array}{c}0.48 * * \\
(7.13) \\
\end{array}$ & $\begin{array}{c}0.45^{* * *} \\
(6.80) \\
\end{array}$ \\
\hline$R^{2}$ & 0.00 & 0.01 & 0.01 & 0.01 & 0.00 & 0.01 & 0.00 & 0.01 \\
\hline No. of obs. & 1,196 & 1,193 & 1,031 & 1,029 & 1,196 & 1,193 & 1,031 & 1,029 \\
\hline
\end{tabular}




\section{Appendix Table 3}

Information Content of Expected Future Performance Rankings

Appendix Table 3 reports the results of pooled time-series cross-sectional OLS regressions of future excess returns $\left(\mathrm{PERF}_{i, t+1}\right)$ or Fama-French 3 -factor alpha (3F_ALPHA $\mathrm{F}_{i, t+1}$ ) rankings on expected future performance rankings and other variables. PERF $F_{i, t+l}$ and 3F_ALPHA $\mathrm{F}_{i, t+1}$ are computed for the one-year and two-year periods starting one week after the last fielding date of the survey. PAST_EX_RET ${ }_{i, t}$ and PAST_3F_ALPHA ${ }_{i, t}$ are computed for the two-year periods finishing at the end of the month preceding the first fielding date of the survey. Excess returns, 3-factor alphas, expected future performance, reported past performance, and soft investment factor and service factor rankings are expressed using the fractional rank of each asset manager in the sample. An asset manager's fractional rank, for a given variable, represents its percentile rank relative to other asset managers in the same period, and ranges from zero to one. All regressions also include a measure of the number of investment consultants' recommendations received (over the total possible) by the asset manager, lagged log assets under management, and return volatility. Each column represents a separate regression. $t$-statistics based on standard errors clustered at the asset manager level are included in parenthesis. $*$ and $* *$ indicate statistical significance at the $5 \%$ and $1 \%$ levels, respectively.

\begin{tabular}{|c|c|c|c|c|c|c|c|c|}
\hline \multirow[b]{3}{*}{ EXPECTED_PERF $_{i, t}$} & \multicolumn{4}{|c|}{ Excess Return Ranking } & \multicolumn{4}{|c|}{ 3-Factor Alpha Ranking } \\
\hline & \multicolumn{2}{|c|}{ 1-Year } & \multicolumn{2}{|c|}{ 2-Year } & \multicolumn{2}{|c|}{ 1-Year } & \multicolumn{2}{|c|}{ 2-Year } \\
\hline & $\begin{array}{c}-0.04 \\
(-0.98)\end{array}$ & $\begin{array}{c}-0.03 \\
(-0.73)\end{array}$ & $\begin{array}{c}0.01 \\
(0.11)\end{array}$ & $\begin{array}{c}-0.01 \\
(-0.32)\end{array}$ & $\begin{array}{c}-0.07 \\
(-1.79)\end{array}$ & $\begin{array}{c}-0.04 \\
(-1.18)\end{array}$ & $\begin{array}{c}0.02 \\
(0.43)\end{array}$ & $\begin{array}{c}-0.01 \\
(-0.20)\end{array}$ \\
\hline REPORTED_PAST_PERF $_{i, t}$ & $\begin{array}{c}0.05 \\
(1.33)\end{array}$ & & $\begin{array}{c}-0.05 \\
(-0.99)\end{array}$ & & $\begin{array}{l}0.08 * \\
(2.23)\end{array}$ & & $\begin{array}{c}-0.04 \\
(-0.79)\end{array}$ & \\
\hline PAST_EX_RET ${ }_{i, t}$ & & $\begin{array}{c}0.05 \\
(1.80)\end{array}$ & & $\begin{array}{c}-0.03 \\
(-0.77)\end{array}$ & & & & \\
\hline PAST_3F_ALPHA ${ }_{i, t}$ & & & & & & $\begin{array}{l}0.08 * \\
(2.45)\end{array}$ & & $\begin{array}{c}0.05 \\
(1.37)\end{array}$ \\
\hline SOFT_INV_FACTORS $_{i, t}$ & $\begin{array}{c}-0.05 \\
(-1.20)\end{array}$ & $\begin{array}{c}-0.05 \\
(-1.20)\end{array}$ & $\begin{array}{c}-0.03 \\
(-0.62)\end{array}$ & $\begin{array}{c}-0.04 \\
(-1.03)\end{array}$ & $\begin{array}{c}-0.01 \\
(-0.25)\end{array}$ & $\begin{array}{c}-0.00 \\
(-0.06)\end{array}$ & $\begin{array}{c}-0.03 \\
(-0.73)\end{array}$ & $\begin{array}{c}-0.05 \\
(-1.12)\end{array}$ \\
\hline SERVICE_FACTORS $_{i, t}$ & $\begin{array}{c}0.05 \\
(1.40)\end{array}$ & $\begin{array}{c}0.05 \\
(1.53)\end{array}$ & $\begin{array}{c}0.03 \\
(0.89)\end{array}$ & $\begin{array}{c}0.03 \\
(0.93)\end{array}$ & $\begin{array}{c}-0.01 \\
(-0.16)\end{array}$ & $\begin{array}{c}-0.00 \\
(-0.08)\end{array}$ & $\begin{array}{c}0.02 \\
(0.45)\end{array}$ & $\begin{array}{c}0.02 \\
(0.44)\end{array}$ \\
\hline CONSULTANTS_RECS $_{i, t}$ & $\begin{array}{c}-0.04 \\
(-0.22)\end{array}$ & $\begin{array}{c}-0.03 \\
(-0.19)\end{array}$ & $\begin{array}{c}-0.30 \\
(-1.31)\end{array}$ & $\begin{array}{c}-0.28 \\
(-1.23)\end{array}$ & $\begin{array}{c}0.04 \\
(0.21)\end{array}$ & $\begin{array}{c}0.05 \\
(0.27)\end{array}$ & $\begin{array}{c}-0.09 \\
(-0.42)\end{array}$ & $\begin{array}{c}-0.08 \\
(-0.35)\end{array}$ \\
\hline $\mathrm{TNA}_{i, t-1}$ & $\begin{array}{c}-0.00 \\
(-0.85)\end{array}$ & $\begin{array}{c}-0.00 \\
(-0.87)\end{array}$ & $\begin{array}{c}-0.00 \\
(-0.28)\end{array}$ & $\begin{array}{c}-0.00 \\
(-0.24)\end{array}$ & $\begin{array}{c}-0.00 \\
(-0.69)\end{array}$ & $\begin{array}{c}-0.00 \\
(-0.91)\end{array}$ & $\begin{array}{c}-0.00 \\
(-0.17)\end{array}$ & $\begin{array}{c}-0.00 \\
(-0.13)\end{array}$ \\
\hline RETURN_VOL $_{i, t-1}$ & $\begin{array}{c}0.02 \\
(0.12)\end{array}$ & $\begin{array}{c}0.03 \\
(0.21)\end{array}$ & $\begin{array}{c}0.13 \\
(0.54)\end{array}$ & $\begin{array}{c}0.12 \\
(0.51)\end{array}$ & $\begin{array}{c}-0.13 \\
(-0.75)\end{array}$ & $\begin{array}{c}-0.14 \\
(-0.83)\end{array}$ & $\begin{array}{c}0.19 \\
(0.85)\end{array}$ & $\begin{array}{c}0.19 \\
(0.84)\end{array}$ \\
\hline INTERCEPT & $\begin{array}{l}0.50 * * \\
(10.44)\end{array}$ & $\begin{array}{c}0.49 * * \\
(9.98)\end{array}$ & $\begin{array}{c}0.49 * * \\
(7.56)\end{array}$ & $\begin{array}{c}0.49 * * \\
(7.48)\end{array}$ & $\begin{array}{c}0.53 * * \\
(10.16)\end{array}$ & $\begin{array}{l}0.52 * * \\
(10.08)\end{array}$ & $\begin{array}{c}0.48 * * \\
(7.08) \\
\end{array}$ & $\begin{array}{c}0.45 * * \\
(6.79) \\
\end{array}$ \\
\hline$R^{2}$ & 0.00 & 0.01 & 0.01 & 0.01 & 0.01 & 0.01 & 0.00 & 0.01 \\
\hline No. of obs. & 1,196 & 1,193 & 1,031 & 1,029 & 1,196 & 1,193 & 1,031 & 1,029 \\
\hline
\end{tabular}




\section{Appendix Table 4 \\ Effect of Past and Expected Performance, Soft Investment Factors, Service Factors, and Consultants' Recommendations on Asset Flows}

Appendix Table 4 reports the results of pooled time-series cross-sectional regressions of asset managers' yearly asset flows on lagged past, and expected future, investment performance, variables measuring soft investment factors and service factors, and investment consultants' recommendations. The sample includes asset managers' U.S. active equity products only. These products are aggregated into a single observation for each asset manager-year. Asset flows are expressed as percentages of total assets under management at the end of the previous year. Past performance is proxied using reported past performance (in the survey) or the excess return computed over the two-year period finishing at the end of the month preceding the first fielding date of the previous year survey. Past and expected future performance, soft investment factors, and service factors are expressed using the fractional rank of each asset manager in the sample. An asset manager's fractional rank, for a given variable, represents its percentile rank relative to other asset managers in the same period, and ranges from zero to one. The change in consultants' recommendations is the change in the percentage of short list recommendations received over the total possible. All regressions also include a lagged measure of log assets under management, return volatility and a full set of time dummies (which are not reported in the table). Each column represents a separate regression. $t$-statistics based on standard errors clustered at the product level are included in parenthesis. * and $* *$ indicate statistical significance at the $5 \%$ and $1 \%$ levels, respectively. 


\begin{tabular}{|c|c|c|c|c|c|c|}
\hline & 1 & 2 & 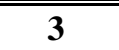 & 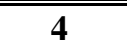 & 5 & 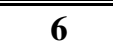 \\
\hline EXPECTED_PERF $_{i, t-1}$ & $\begin{array}{c}-0.01 \\
(-0.15)\end{array}$ & $\begin{array}{c}-0.01 \\
(-0.25)\end{array}$ & $\begin{array}{c}-0.05 \\
(-1.16)\end{array}$ & $\begin{array}{c}0.10 * * \\
(3.19)\end{array}$ & $\begin{array}{l}0.06^{*} \\
(2.07)\end{array}$ & $\begin{array}{c}-0.03 \\
(-0.70)\end{array}$ \\
\hline EXPECTED_PERF $_{i, t-2}$ & & & $\begin{array}{c}0.06 \\
(1.40)\end{array}$ & & $\begin{array}{c}0.06 \\
(1.76)\end{array}$ & \\
\hline REPORTED_PAST_PERF $F_{i, t-1}$ & $\begin{array}{c}0.32 * * \\
(7.84)\end{array}$ & $\begin{array}{c}0.31 * * \\
(7.93)\end{array}$ & $\begin{array}{c}0.31 * * \\
(6.91)\end{array}$ & & & $\begin{array}{c}0.31 * * \\
(7.61)\end{array}$ \\
\hline REPORTED_PAST_PERF $F_{i, t-2}$ & & & $\begin{array}{c}0.02 \\
(0.68)\end{array}$ & & & \\
\hline PAST_EX_RET $T_{i, t-1}$ & & & & $\begin{array}{l}0.31 * * \\
(10.88)\end{array}$ & $\begin{array}{l}0.27 * * \\
(7.64)\end{array}$ & \\
\hline PAST_EX_RET ${ }_{i, t-2}$ & & & & & $\begin{array}{c}0.04 \\
(1.38)\end{array}$ & \\
\hline SOFT_INV_FACTORS ${ }_{i, t-1}$ & $\begin{array}{l}-0.08 \\
(-1.75)\end{array}$ & $\begin{array}{l}-0.08 \\
(-1.74)\end{array}$ & $\begin{array}{c}-0.05 \\
(-1.20)\end{array}$ & $\begin{array}{c}-0.01 \\
(-0.27)\end{array}$ & $\begin{array}{c}0.01 \\
(0.36)\end{array}$ & \\
\hline SOFT_INV_FACTORS $S_{i, t-2}$ & & & $\begin{array}{c}-0.05 \\
(-0.82)\end{array}$ & & $\begin{array}{c}-0.03 \\
(-0.54)\end{array}$ & \\
\hline - Consistent Inv. Philosophy (t-1) & & & & & & $\begin{array}{c}0.02 \\
(0.51)\end{array}$ \\
\hline - Clear Decision Making (t-1) & & & & & & $\begin{array}{c}-0.09 \\
(-1.76)\end{array}$ \\
\hline - Capable Inv. Professionals (t-1) & & & & & & $\begin{array}{c}0.01 \\
(0.17)\end{array}$ \\
\hline SERVICE_FACTORS $_{i, t-1}$ & $\begin{array}{c}0.01 \\
(0.41)\end{array}$ & $\begin{array}{c}0.03 \\
(0.72)\end{array}$ & $\begin{array}{c}0.01 \\
(0.32)\end{array}$ & $\begin{array}{c}0.00 \\
(0.14)\end{array}$ & $\begin{array}{c}-0.01 \\
(-0.45)\end{array}$ & \\
\hline SERVICE_FACTORS $_{i, t-2}$ & & & $\begin{array}{c}0.01 \\
(0.30)\end{array}$ & & $\begin{array}{c}0.01 \\
(0.34)\end{array}$ & \\
\hline - Understanding of Objectives (t-1) & & & & & & $\begin{array}{c}0.00 \\
(0.04)\end{array}$ \\
\hline - Relationship Manager (t-1) & & & & & & $\begin{array}{c}-0.03 \\
(-0.71)\end{array}$ \\
\hline - Credibility (t-1) & & & & & & $\begin{array}{c}-0.01 \\
(-0.18)\end{array}$ \\
\hline - Useful Written Reports (t-1) & & & & & & $\begin{array}{c}-0.06 \\
(-1.31)\end{array}$ \\
\hline - Useful Formal Meetings (t-1) & & & & & & $\begin{array}{c}0.05 \\
(1.10)\end{array}$ \\
\hline - Useful Informal Meetings (t-1) & & & & & & $\begin{array}{c}0.07 \\
(1.63)\end{array}$ \\
\hline$\Delta$ CONSULTANTS_RECS $S_{i, t-1}$ & & $\begin{array}{c}0.68 * * \\
(3.79)\end{array}$ & $\begin{array}{c}0.54 * * \\
(2.73)\end{array}$ & $\begin{array}{l}0.57 * * \\
(3.17)\end{array}$ & $\begin{array}{l}0.47 * \\
(2.57)\end{array}$ & $\begin{array}{c}0.68 * * \\
(3.76)\end{array}$ \\
\hline $\mathrm{TNA}_{i, t-1}$ & $\begin{array}{l}-0.01 \\
(-1.45)\end{array}$ & $\begin{array}{l}-0.01 \\
(-1.46)\end{array}$ & $\begin{array}{l}-0.01 \\
(-1.23)\end{array}$ & $\begin{array}{l}-0.00 \\
(-0.72)\end{array}$ & $\begin{array}{c}-0.00 \\
(-0.18)\end{array}$ & $\begin{array}{c}-0.01 \\
(-1.51)\end{array}$ \\
\hline RETURN_VOL $_{i, t-1}$ & $\begin{array}{c}-0.37 \\
(-0.89) \\
\end{array}$ & $\begin{array}{c}-0.38 \\
(-0.89) \\
\end{array}$ & $\begin{array}{c}-0.86 \\
(-1.92) \\
\end{array}$ & $\begin{array}{c}-0.72 \\
(-1.75) \\
\end{array}$ & $\begin{array}{c}-1.15^{* *} \\
(-2.65) \\
\end{array}$ & $\begin{array}{c}-0.43 \\
(-0.98)\end{array}$ \\
\hline Year Dummies & Yes & Yes & Yes & Yes & Yes & Yes \\
\hline$R^{2}$ & 0.15 & 0.15 & 0.17 & 0.18 & 0.19 & 0.16 \\
\hline No. of obs. & 1,207 & 1,169 & 1,044 & 1,157 & 1,035 & 1,169 \\
\hline
\end{tabular}




\section{Appendix Table 5 \\ Effect of Past and Expected Performance, Soft Investment Factors, Service Factors, and Consultants' Recommendations on Asset Flows - Additional Past Performance Measures}

Appendix Table 5 reports the results of pooled time-series cross-sectional regressions of asset managers' yearly asset flows on lagged past, and expected future, investment performance, variables measuring soft investment factors and service factors, and investment consultants' recommendations. The sample includes asset managers' U.S. active equity products only. These products are aggregated into a single observation for each asset manager-year. Asset flows are expressed as percentages of total assets under management at the end of the previous year. Past performance is proxied using several measures: the excess return and 3-factor alphas (also the one-year excess return and 3-factor alphas) computed over the two-year (one-year) period finishing at the end of the month preceding the first fielding date of the previous year survey. Past and expected future performance, soft investment factors and service factors are expressed using the fractional rank of each asset manager in the sample. An asset manager's fractional rank, for a given variable, represents its percentile rank relative to other asset managers in the same period, and ranges from zero to one. The change in consultants' recommendations is the change in the percentage of short list recommendations received over the total possible. All regressions also include a lagged measure of log assets under management, return volatility, and a full set of time dummies (which are not reported in the table). Each column represents a separate regression. $t$-statistics based on standard errors clustered at the product level are included in parenthesis. $*$ and $* *$ indicate statistical significance at the $5 \%$ and $1 \%$ levels, respectively. 


\begin{tabular}{|c|c|c|c|c|c|c|}
\hline & 1 & 2 & 3 & 4 & 5 & 6 \\
\hline EXPECTED_PERF $_{i, t-1}$ & $\begin{array}{l}0.12 * * \\
(3.58)\end{array}$ & $\begin{array}{l}0.09^{*} \\
(2.59)\end{array}$ & $\begin{array}{l}0.10^{* *} \\
(3.17)\end{array}$ & $\begin{array}{l}0.07^{*} \\
(2.14)\end{array}$ & $\begin{array}{l}0.10^{* *} \\
(3.09)\end{array}$ & $\begin{array}{c}0.05 \\
(1.54)\end{array}$ \\
\hline EXPECTED_PERF $_{i, t-2}$ & & $\begin{array}{c}0.05 \\
(1.56)\end{array}$ & & $\begin{array}{c}0.05 \\
(1.52)\end{array}$ & & $\begin{array}{c}0.06 \\
(1.87)\end{array}$ \\
\hline PAST_EX_RET ${ }_{i, t-1}$ & & & $\begin{array}{l}0.20 * * \\
(4.05)\end{array}$ & $\begin{array}{l}0.15^{* *} \\
(2.61)\end{array}$ & $\begin{array}{l}0.11^{*} \\
(2.30)\end{array}$ & $\begin{array}{c}-0.09 \\
(-1.06)\end{array}$ \\
\hline PAST_EX_RET ${ }_{i, t-2}$ & & & & $\begin{array}{c}0.05 \\
(1.03)\end{array}$ & & $\begin{array}{l}0.13^{*} \\
(2.33)\end{array}$ \\
\hline 1Y_PAST_EX_RET ${ }_{i, t-1}$ & & & & & $\begin{array}{c}0.15^{* *} \\
(2.95)\end{array}$ & $\begin{array}{l}0.26 * * \\
(3.87)\end{array}$ \\
\hline 1Y_PAST_EX_RET ${ }_{i, t-2}$ & & & & & & $\begin{array}{c}0.05 \\
(0.69)\end{array}$ \\
\hline PAST_3F_ALPHA $A_{i, t-1}$ & $\begin{array}{c}0.30 * * \\
(9.24)\end{array}$ & $\begin{array}{c}0.27 * * \\
(7.76)\end{array}$ & $\begin{array}{l}0.16 * * \\
(2.91)\end{array}$ & $\begin{array}{l}0.17 * * \\
(2.89)\end{array}$ & $\begin{array}{l}0.16 * * \\
(2.99)\end{array}$ & $\begin{array}{l}0.19^{*} \\
(2.51)\end{array}$ \\
\hline PAST_3F_ALPHA $A_{i, t-2}$ & & $\begin{array}{c}0.03 \\
(0.92)\end{array}$ & & $\begin{array}{l}-0.01 \\
(-0.20)\end{array}$ & & $\begin{array}{c}0.01 \\
(0.10)\end{array}$ \\
\hline 1Y_PAST_3F_ALPHA $A_{i, t-1}$ & & & & & $\begin{array}{c}-0.03 \\
(-0.54)\end{array}$ & $\begin{array}{c}-0.03 \\
(-0.45)\end{array}$ \\
\hline 1Y_PAST_3F_ALPHA ${ }_{i, t-2}$ & & & & & & $\begin{array}{c}-0.04 \\
(-0.69)\end{array}$ \\
\hline SOFT_INV_FACTORS $_{i, t-1}$ & $\begin{array}{l}-0.00 \\
(-0.01)\end{array}$ & $\begin{array}{c}0.02 \\
(0.51)\end{array}$ & $\begin{array}{l}-0.01 \\
(-0.17)\end{array}$ & $\begin{array}{c}0.02 \\
(0.41)\end{array}$ & $\begin{array}{l}-0.01 \\
(-0.15)\end{array}$ & $\begin{array}{c}0.02 \\
(0.39)\end{array}$ \\
\hline SOFT_INV_FACTORS $_{i, t-2}$ & & $\begin{array}{c}-0.02 \\
(-0.30)\end{array}$ & & $\begin{array}{c}-0.02 \\
(-0.33)\end{array}$ & & $\begin{array}{c}-0.01 \\
(-0.28)\end{array}$ \\
\hline SERVICE_FACTORS $_{i, t-1}$ & $\begin{array}{l}-0.00 \\
(-0.06)\end{array}$ & $\begin{array}{c}-0.02 \\
(-0.62)\end{array}$ & $\begin{array}{l}-0.00 \\
(-0.03)\end{array}$ & $\begin{array}{c}-0.02 \\
(-0.63)\end{array}$ & $\begin{array}{l}-0.00 \\
(-0.05)\end{array}$ & $\begin{array}{l}-0.02 \\
(-0.65)\end{array}$ \\
\hline SERVICE_FACTORS $_{i, t-2}$ & & $\begin{array}{c}0.01 \\
(0.30)\end{array}$ & & $\begin{array}{c}0.01 \\
(0.28)\end{array}$ & & $\begin{array}{c}0.01 \\
(0.21)\end{array}$ \\
\hline$\Delta$ CONSULTANTS_RECS ${ }_{i, t-1}$ & $\begin{array}{c}0.66^{* *} \\
(3.54)\end{array}$ & $\begin{array}{l}0.55^{* * *} \\
(2.88)\end{array}$ & $\begin{array}{c}0.58 * * \\
(3.21)\end{array}$ & $\begin{array}{l}0.48^{*} \\
(2.60)\end{array}$ & $\begin{array}{c}0.64 * * \\
(3.46)\end{array}$ & $\begin{array}{l}0.50^{* *} \\
(2.68)\end{array}$ \\
\hline TNA $_{i, t-1}$ & $\begin{array}{c}-0.01 \\
(-1.17)\end{array}$ & $\begin{array}{c}-0.00 \\
(-0.58)\end{array}$ & $\begin{array}{c}-0.01 \\
(-1.00)\end{array}$ & $\begin{array}{c}-0.00 \\
(-0.42)\end{array}$ & $\begin{array}{c}-0.01 \\
(-1.06)\end{array}$ & $\begin{array}{c}-0.00 \\
(-0.65)\end{array}$ \\
\hline RETURN_VOL $_{i, t-1}$ & $\begin{array}{c}-1.23 * * \\
(-2.78) \\
\end{array}$ & $\begin{array}{r}-1.68 * * \\
(-3.50) \\
\end{array}$ & $\begin{array}{l}-1.02 * \\
(-2.46) \\
\end{array}$ & $\begin{array}{r}-1.46 * * \\
(-3.29) \\
\end{array}$ & $\begin{array}{r}-1.15^{* *} \\
(-2.78) \\
\end{array}$ & $\begin{array}{c}-1.69 * * \\
(-3.84) \\
\end{array}$ \\
\hline Year Dummies & Yes & Yes & Yes & Yes & Yes & Yes \\
\hline$R^{2}$ & 0.18 & 0.19 & 0.19 & 0.20 & 0.20 & 0.22 \\
\hline No. of obs. & 1,157 & 1,035 & 1,157 & 1,035 & 1,157 & 1,035 \\
\hline
\end{tabular}




\section{Appendix Table 6}

The Effect of Investment Performance and Service Quality on Asset Flows: Nonlinearities Appendix Table 6 reports the results of pooled time-series cross-sectional regressions of asset managers' yearly asset flows on lagged past, and expected future, investment performance, variables measuring soft investment factors and service factors, and investment consultants' recommendations. Asset flows are expressed as percentages of total assets under management at the end of the previous year. Past and expected future performance, soft investment factors and service factors are expressed using the fractional rank of each asset manager in the sample. To test for nonlinearities in the flow-performance/service quality relation we estimate separate lagged performance and service factor coefficients for those asset managers ranked above and below a given threshold (defined, alternatively, by the 33rd and 50th percentile of service quality and past performance). PP and SF stand for past performance and service factors respectively. The change in consultants' recommendations is the change in the percentage of short list recommendations received over the total possible. All regressions also include a lagged measure of log assets under management, return volatility, and a full set of time dummies (which are not reported in the table). Each column represents a separate regression. $t$-statistics based on standard errors clustered at the product level are included in parenthesis. $*$ and $* *$ indicate statistical significance at the $5 \%$ and $1 \%$ levels, respectively.

\begin{tabular}{|c|c|c|c|c|c|c|}
\hline & \multicolumn{3}{|c|}{ Threshold 0.5} & \multicolumn{3}{|c|}{ Threshold 0.33} \\
\hline & $\mathbf{1}$ & 2 & 3 & 4 & 5 & 6 \\
\hline EXPECTED_PERF $_{i, t-1}$ & $\begin{array}{c}-0.01 \\
(-0.27)\end{array}$ & $\begin{array}{c}-0.01 \\
(-0.30)\end{array}$ & $\begin{array}{c}-0.01 \\
(-0.27)\end{array}$ & $\begin{array}{c}-0.01 \\
(-0.31)\end{array}$ & $\begin{array}{c}-0.01 \\
(-0.32)\end{array}$ & $\begin{array}{c}-0.01 \\
(-0.28)\end{array}$ \\
\hline EXPECTED_PERF $_{i, t-2}$ & & $\begin{array}{c}0.32 * * \\
(7.95)\end{array}$ & $\begin{array}{c}0.31 * * \\
(7.92)\end{array}$ & & $\begin{array}{c}0.32 * * \\
(7.99)\end{array}$ & $\begin{array}{c}0.33 * * \\
(7.94)\end{array}$ \\
\hline REPORTED_PAST_PERF $\times \mathrm{I}(\mathrm{PP}<\mathrm{thr} \text {. })_{i, t-1}$ & $\begin{array}{c}0.42 * * \\
(4.76)\end{array}$ & & & $\begin{array}{c}0.49 * * \\
(3.83)\end{array}$ & & \\
\hline REPORTED_PAST_PERF $\times I(\mathrm{PP}>\text { thr. })_{i, t-1}$ & $\begin{array}{c}0.22 * * \\
(3.34)\end{array}$ & & & $\begin{array}{c}0.26^{* * *} \\
(5.35)\end{array}$ & & \\
\hline SOFT_INV_FACTORS $S_{i, t-1}$ & $\begin{array}{c}-0.08 \\
(-1.72)\end{array}$ & $\begin{array}{c}-0.08 \\
(-1.76)\end{array}$ & $\begin{array}{c}-0.08 \\
(-1.76)\end{array}$ & $\begin{array}{c}-0.08 \\
(-1.74)\end{array}$ & $\begin{array}{l}-0.08 \\
(-1.78)\end{array}$ & $\begin{array}{c}-0.08 \\
(-1.76)\end{array}$ \\
\hline SERVICE_FACTORS $_{i, t-1}$ & $\begin{array}{c}0.02 \\
(0.65)\end{array}$ & & & $\begin{array}{c}0.02 \\
(0.67)\end{array}$ & & \\
\hline SERVICE_FACTORS $\times \mathrm{I}(\mathrm{SF}<\mathrm{thr} .)_{i, t-1}$ & & $\begin{array}{c}0.13 \\
(1.92)\end{array}$ & & & $\begin{array}{l}0.26^{*} \\
(2.15)\end{array}$ & \\
\hline SERVICE_FACTORS $\times$ I $(\mathrm{SF}>\text { thr. })_{i, t-1}$ & & $\begin{array}{l}-0.07 \\
(-1.12)\end{array}$ & & & $\begin{array}{c}-0.04 \\
(-0.97)\end{array}$ & \\
\hline SERVICE_FACTORS $\times \mathrm{I}(\mathrm{PP}<\mathrm{thr} .)_{i, t-1}$ & & & $\begin{array}{c}0.05 \\
(1.03)\end{array}$ & & & $\begin{array}{c}0.09 \\
(1.67)\end{array}$ \\
\hline SERVICE_FACTORS $\times$ I $(\mathrm{PP}>\text { thr. })_{i, t-1}$ & & & $\begin{array}{c}0.01 \\
(0.16)\end{array}$ & & & $\begin{array}{c}0.00 \\
(0.05)\end{array}$ \\
\hline$\Delta$ CONSULTANTS_RECS ${ }_{i, t-1}$ & $\begin{array}{c}0.68 * * \\
(3.80)\end{array}$ & $\begin{array}{c}0.70 * * \\
(3.88)\end{array}$ & $\begin{array}{c}0.67 * * \\
(3.69)\end{array}$ & $\begin{array}{c}0.69 * * \\
(3.82)\end{array}$ & $\begin{array}{c}0.70 * * \\
(3.91)\end{array}$ & $\begin{array}{c}0.69 * * \\
(3.82)\end{array}$ \\
\hline $\mathrm{TNA}_{i, t-1}$ & $\begin{array}{c}-0.02 \\
(-1.56)\end{array}$ & $\begin{array}{c}-0.02 \\
(-1.60)\end{array}$ & $\begin{array}{c}-0.01 \\
(-1.46)\end{array}$ & $\begin{array}{l}-0.02 \\
(-1.56)\end{array}$ & $\begin{array}{c}-0.02 \\
(-1.64)\end{array}$ & $\begin{array}{c}-0.01 \\
(-1.43)\end{array}$ \\
\hline RETURN_VOL $_{i, t-1}$ & $\begin{array}{c}-0.36 \\
(-0.84)\end{array}$ & $\begin{array}{c}-0.41 \\
(-0.95)\end{array}$ & $\begin{array}{c}-0.39 \\
(-0.90)\end{array}$ & $\begin{array}{c}-0.38 \\
(-0.89)\end{array}$ & $\begin{array}{c}-0.44 \\
(-1.03)\end{array}$ & $\begin{array}{c}-0.40 \\
(-0.92)\end{array}$ \\
\hline $\begin{array}{l}\text { Test Past Perf }(+)=\text { Past Perf }(-) \\
\text { Test Serv. Fact. }(+)=\text { Serv. Fact. }(-)\end{array}$ & 0.13 & 0.07 & 0.63 & 0.12 & $0.03 *$ & 0.13 \\
\hline Year Dummies & Yes & Yes & Yes & Yes & Yes & Yes \\
\hline$R^{2}$ & 0.15 & 0.16 & 0.15 & 0.16 & 0.16 & 0.15 \\
\hline No. of obs. & 1,169 & 1,169 & 1,169 & 1,169 & 1,169 & 1,169 \\
\hline
\end{tabular}




\section{Appendix Table 7}

\section{Actual Versus Reported Past Performance and Asset Flows}

Appendix Table 7 reports the coefficients of lagged reported past performance (survey) and past excess return or 3-factor alpha rankings on a regressions of asset managers' yearly asset flows on these and additional variables. In these regressions asset flows are expressed as percentages of total assets under management at the end of the previous year. Past excess return and 3-factor alpha performance rankings are computed using one, two- and three-year fund returns for the periods ending at the end of the month preceding the first fielding date of the survey. Past excess returns, 3 -factor alphas, reported past performance, and the rest of the variables included in the regression are expressed using the fractional percentiles. Although not reported, all regressions also include lagged expected future investment performance, soft service and investment quality rankings, consultants' recommendations, log assets under management, return volatility and a full set of time dummies. Each column reports the coefficients of a separate regression. $t$-statistics based on standard errors clustered at the product level are included in parenthesis. * and $* *$ indicate statistical significance at the $5 \%$ and $1 \%$ levels, respectively.

\begin{tabular}{|c|c|c|c|c|c|c|}
\hline & \multicolumn{3}{|c|}{ Excess Return } & \multicolumn{3}{|c|}{ 3-Factor Alpha } \\
\hline & 1-Year & 2-Year & 3-Year & 1-Year & 2-Year & 3-Year \\
\hline REPORTED_PAST_PERF $_{i, t-1}$ & $\begin{array}{c}0.22 * * \\
(6.00)\end{array}$ & $\begin{array}{c}0.16^{* *} \\
(4.18)\end{array}$ & $\begin{array}{c}0.18 * * \\
(4.42)\end{array}$ & $\begin{array}{c}0.25^{* *} \\
(6.81)\end{array}$ & $\begin{array}{c}0.20 * * \\
(5.49)\end{array}$ & $\begin{array}{c}0.21^{* * *} \\
(5.98)\end{array}$ \\
\hline $\mathrm{PAST}_{\mathrm{EX}} \mathrm{ERET}_{i, t-1} / \mathrm{PAST} \_3 \mathrm{~F}_{-} \mathrm{ALPHA}_{i, t-1}$ & $\begin{array}{c}0.22 * * \\
(6.99)\end{array}$ & $\begin{array}{c}0.24 * * \\
(7.58)\end{array}$ & $\begin{array}{c}0.21 * * \\
(6.84)\end{array}$ & $\begin{array}{c}0.18 * * \\
(5.26)\end{array}$ & $\begin{array}{c}0.24 * * \\
(6.93)\end{array}$ & $\begin{array}{c}0.19 * * \\
(6.13)\end{array}$ \\
\hline$R^{2}$ & 0.19 & 0.19 & 0.20 & 0.18 & 0.20 & 0.20 \\
\hline No. of obs. & 1,160 & 1,157 & 1,152 & 1,160 & 1,157 & 1,152 \\
\hline
\end{tabular}




\section{Appendix Figure 1}

\section{Combined Sample: Level of Analysis}

Greenwich Associates' (GA) plan sponsors' survey is at the asset manager/asset class level containing one score for each asset manager in each asset class (e.g. Fidelity U.S. Active Equities, Fidelity U.S. Active Fixed Income, Fidelity U.K. Active Equities, etc.). The GA consultants' recommendations survey is at the level of each asset manager/size-style category (e.g. Fidelity Large Cap Growth, Fidelity Mid Cap Value, etc.). The eVestment database has performance and assets under management data for individual funds (e.g. Fidelity Mid Cap Value Fund, Fidelity Small Cap Growth Fund, etc.) within a complex. In the majority of cases, there is only one individual fund per manager-size-style category.

\begin{tabular}{l|l|l}
\hline Level of & $\begin{array}{l}\text { Source } \\
\text { of Data }\end{array}$ & Stylized \\
\hline Analysis & Example \\
\hline
\end{tabular}

\begin{tabular}{|c|c|c|}
\hline $\begin{array}{l}\text { Asset } \\
\text { manager/asset } \\
\text { class level }\end{array}$ & $\begin{array}{l}\text { GA survey of plan } \\
\text { sponsors' views on asset } \\
\text { managers' non- } \\
\text { performance factors }\end{array}$ & Firm XYZ Active U.S. Equities \\
\hline
\end{tabular}

$\begin{array}{lllllllll}\begin{array}{l}\text { Size-style } \\ \text { level }\end{array} & \begin{array}{l}\text { GA survey of } \\ \text { consultants' } \\ \text { recommendations of } \\ \text { funds by size-style } \\ \text { category }\end{array} & \begin{array}{l}\text { XYZ } \\ \text { Large } \\ \text { Cap } \\ \text { Growth }\end{array} & \begin{array}{l}\text { XYZ } \\ \text { Large Cap } \\ \text { Value }\end{array} & \begin{array}{l}\text { XYZ Mid } \\ \text { Cap } \\ \text { Growth }\end{array} & \begin{array}{l}\text { XYZ Mid } \\ \text { Cap Value }\end{array} & \begin{array}{l}\text { XYZ Small } \\ \text { Cap Growth }\end{array} & \begin{array}{l}\text { XYZ Small } \\ \text { Cap Value }\end{array} & \begin{array}{l}\text { XYZ } \\ \text { Core } \\ \text { Equity }\end{array} \\ \text { Fund level } & \begin{array}{l}\text { eVestment flows and } \\ \text { performance database } \\ \text { by individual fund }\end{array} & \text { Fund 1 } & \begin{array}{l}\text { Fund 1 } \\ \text { Fund 2 } \\ \text { etc... }\end{array} & \text { Fund 1 } & \text { Fund 1 } & \text { Fund 1 } & \text { Fund 1 } & \text { Fund 1 } \\ & & & & & & & & \text { Fund 2 } \\ \end{array}$

